\title{
COMMENTS
}

\section{The Philadelphia Plan: A Study in the Dynamics of Executive Power}

In 1941, President Roosevelt issued the first in a series of executive orders designed to help combat employment discrimination by government contractors. These orders were the only fair employment initiatives taken by the federal government until Congress enacted the comprehensive Civil Rights Act of 1964, ${ }^{1}$ Titles $\mathrm{VI}^{2}$ and $\mathrm{VII}^{3}$ of which imposed special fair employment obligations on both contractors with the federal government and contractors working on federally assisted projects. Subsequent to the enactment of this legislation, President Johnson issued another executive order-No. 11,246-governing nondiscrimination by these contractors. Assertedly pursuant to a delegation of power contained in that Order, ${ }^{4}$ the Secretary of Labor, in 1969, promulgated the Philadelphia Plan, 5 requiring that contractors make

142 U.S.C. $\$ \S 2000 \mathrm{a}$ to h-6 (1970).

$2 I d$. $\S$ 2000d to d-4 (1970).

3 Id. $\$ \S 2000 \mathrm{e}$ to e -15 (1970).

43 G.F.R. 339 (1964-65 Comp.), 42 U.S.C. $\$ 2000$ e (1970). The delegation of power relied on by the Secretary of Labor is contained in section 201 of the Order: "The Secretary of Labor shall be responsible for the administration of Parts II and III of this Order and shall adopt such rules and regulations and issue such orders as he deems necessary and appropriate to achieve the purposes thereof."

5 The Plan was issued to the heads of all federal agencies on June 27, 1969. For the text of the Plan, see 1 CCH Employment Practrces Guide 1708 (1972) [hereinafter cited as Text of Plan]. An order implementing the Plan was issued on September 23, 1969. I CCH EMployment Practices GuIDE I 1710 (1972) [hereinafter cited as Implementation Order]. The Plan was extended, effective March 1, 1971, to include all construction activities of covered contractors and subcontractors. Text of Plan, supra. It appears that the Plan was, in fact, developed primarily under the auspices of Assistant Secretary of Labor Fletcher; both the Plan and the Implementation Order went out under his signature, without formal approval by Secretary of Labor Shultz. A challenge to the Plan on this ground was rejected in Contractors Ass'n v. Secretary of Labor, 442 F.2d 159, 175-76 (3d Cir. 1971), in which the Secretary was deemed to have properly delegated to Mr. Fletcher his authority under Executive Order No. 11,246. This ruling is probably erroneous since section 401 of the Order specifically forbade the Secretary to delegate his "authority to promulgate rules and regulations of a general nature." 3 C.F.R. 339, 347 (1964-65 Comp.), 42 U.S.C. $\& 2000$ e (1970). The court acted reasonably, however, in attaching little weight to this technicality since Mr. Shultz surely knew of and acquiesced in the Plan from the outset. 
good faith efforts to achieve certain "goals" of minority employment."

Opponents of the Plan have argued that it is inconsistent with the provisions of Titles VI and VII and therefore was beyond the power of the executive branch to institute. ${ }^{7}$ The Plan's supporters have argued, on the contrary, that the Plan is consistent with these Titles, if not as they were originally drafted, at least as they have come to be interpreted both by Congress and the courts. ${ }^{8}$ These arguments are complex, and their resolution is possible only on the basis of a rather detailed chronological account of the events that preceded promulgation of the Philadelphia Plan. This comment attempts to provide the historical perspective needed to address the question whether the Plan conflicts with the provisions of the Givil Rights Act of 1964. It then demonstrates that the kind of "affirmative action" required of contractors by the Plan was indeed inconsistent with that permitted by Titles VI and VII and that its institution was, therefore, beyond the power of the executive branch. ${ }^{9}$

But that is not the end of the matter. In 1972, Title VII was revised and reenacted. In the process, the executive order program was

6 For a description of the Plan's requirements, see text and notes at notes 91-108 infra.

7 Opponents of the Plan have not been widely published. The main arguments against the Plan can be found in Subcomm. on Separation of Powers of Senate Comm. on the Judratary, 92D Cong., 1st Sess., Congresstonal Oversicht of Administrative Agencles -The Phmadelphia Pxan (Comm. Print 1971). See also 49 Comp. Gen. 59 (1969), which holds that the Plan is a violation of Titles VI and VII of the Civil Rights Act of 1964.

8 In the last three years there has been no lack of commentary defending the legality of the program. See Jones, The Bugaboo of Employment Quotas, 1970 Wis. L. REv. 341; Leiken, Preferential Treatment in the Skilled Building Trades: An Analysis of the Philadelphia Plan. 56 CoRNerr L.Q. 84 (1970); Note, The Philadelphia Plan: Equal Employment Opportunity in the Construction Trades, 6 Colum. J.L. \& Soc. ProB. 187 (1970); Note, The Legality of the "Revised" Philadelphia Plan, 30 MD. L. REv. 113 (1970); Note, Executive Order 11,246: Anti-Discrimination Obligations in Government Contracts, 44 N.Y.U.L. REv. 590 (1969); Note, The Philadelphia Plan, 45 Notre Dame LAw. 678 (1970); Comment, The Constitutionality of "Affirmative Action" to Integrate Construction Trades: The Philadelphia Plan, 43 TEMP. L.Q. 329 (1970); Comment, The Philadelphia Plan and Strict Racial Quotas in Federal Contracts, 17 U.G.L.A.L. Rev. 817 (1970). Persuasive support for executive action to end employment discrimination can be found in 42 Or. ATT'Y GEN. 592 (1961) (on the legal authority for Exec. Order No. 10,925); and Solicitor of Labor, Legal Memorandum, Authority under Exec. Order No. 11,246, in Hearings on the Philadelphia Plan and S. 931 Before the Subcomm. on Separation of Powers of the Senate Comm. on the Judiciary, 9lst Cong., 1st Sess., 255 (1969).

For useful overviews of the problems of drafting and enforcing fair employment laws, see Fiss, $A$ Theory of Fair Employment Laws, 38 U. CHI. L. REv. 235 (1971); Gardner, The Development of the Meaning of Title VII of the Civil Rights Acts of 1964, 23 ALA. L. REv. 451 (1971); Developments in the Law-Employment Discrimination and Title VII of the Civil Rights Act of 1964, 84 HaRv. L. Rev. 1109 (1971); cf. Coney, Affirmative Action Dents the National Labor Policy, 10 DuQuesNe L. Rev. 1 (1972); Nash, Affirmative Action Under Executive Order 11,246, 46 N.Y.U.L. REv. 225 (1971).

9 See Youngstown Sheet \& Tube Co. v. Sawyer, 343 U.S. 579 (1952). 
subjected to careful scrutiny, and its affirmative action features received explicit congressional approval. ${ }^{10}$ Thus, four years after its inception, the imprimatur of Congress was at last placed upon a fair employment effort that was, essentially, created and instituted independently by the executive. This comment concludes with a discussion of the implications of that development.

\section{The Controversy: A Brief History}

\section{A. The Early Executive Orders}

President Roosevelt initiated the use of the executive order as a device for dealing with discrimination in employment when, in 1941, responding to threats of a mass demonstration by civil rights forces, he issued an order affirming a policy of nondiscrimination in the government and in defense industries. On authority said to be derived from "the Constitution and the statutes of the United States,"11 the order required, as a "prerequisite to the successful conduct of our national defense production effort ..., ,12 that a clause be included in all government defense contracts obligating contractors not to discriminate in employment on the basis of race, creed, color, or national origin. ${ }^{13}$ Two years later the requirement of a nondiscrimination pledge was extended to all federal contracts and subcontracts. ${ }^{14}$ Succeeding Presidents have each contributed one or more executive orders to this program. ${ }^{15}$

The legality of these orders seems to have been a question of less than pressing concern, ${ }^{16}$ perhaps because they had so little impact on the

\footnotetext{
10 See text at notes 168-86 infra.

11 Exec. Order No. 8802, 3 C.F.R. 957 (1938-43 Comp.).

12 Id.

$13 I d$.

14 Exec. Order No. 9346, 3 G.F.R. 1280 (1938-43 Comp.).
}

15 The major executive orders dealing with the obligations of government contractors and subcontractors are: President Roosevelt: Exec. Order No. 8802, 3 C.F.R. 957 (193843 Comp.); Exec. Order No. 9001, 3 C.F.R. 1054 (1938-43 Comp.); Exec. Order No. 9346, 3 C.F.R. 1280 (1938-43 Comp.); President Truman: Exec. Order No. 10,210, 3 C.F.R. 390 (1949-53 Comp.); Exec. Order No. 10,227, 3 C.F.R. 739 (1949-53 Comp.); Exec. Order No. 10,231, 3 C.F.R. 741 (1949-53 Comp.); Exec. Order No. 10,243, 3 C.F.R. 752 (1949-53 Comp.); Exec. Order No. 10,281, 3 G.F.R. 781 (1949-53 Comp.); Exec. Order No. 10,298, 3 C.F.R. 828 (1949-53 Comp.); Exec. Order No. 10,308, 3 C.F.R. 837 (1949-53 Comp.); President Eisenhower: Exec. Order No. 10,479, 3 G.F.R. 961 (1949-53 Comp.); Exec. Order No. 10,557, 3 C.F.R. 218 (1954-58 Comp.); President Kennedy: Exec. Order No. 10,925, 3 C.F.R. 443 (1959-63 Comp.), 5 U.S.C. \$ 3301 (1970); Exec. Order No. 11,114, 3 C.F.R. 774 (1959-63 Comp.), 5 U.S.G. § 3301 (1970); President Johnson: Exec. Order No. 11,246, 3 C.F.R. 339 (1964-65 Comp.), 42 U.S.C. \& 2000e (1970); Exec. Order No. 11,375, 3 C.F.R. 320 (1966-70 Comp.), 42 U.S.C. \$ 2000e (1970).

10 There appear to have been two exceptions to this general indifference: Miller, Government Contracts and Social Control: A Preliminary Inquiry, 41 VA. L. Rev. 27 (1955); 
problem of employment discrimination. The lack of skills among many blacks, widespread skepticism in the black community about the sincerity of offers of nondiscriminatory employment, a cumbersome and ineffective enforcement mechanism, and evasion of the program's stric. tures combined to leave the position of minority workers essentially unchanged. ${ }^{17}$

By 1961, the executive branch of the government had concluded that the problem resulted not so much from hostility by employers toward minority employees as from their indifference to the difficulties that these employees face. Employers, who considered black workers an unskilled labor pool, unsuited to changing industrial needs, believed that they had no responsibility to make a special effort to deal with black employment problems. The paucity of black applicants for many jobs was similarly accepted as a fact of life not calling for remedial action by hiring authorities. ${ }^{18}$ The proper way to remedy the problem, therefore, seemed simple enough: the government should require "affirmative action" by employers to insure that discrimination did not occur. This requirement, first imposed on government contractors by executive order in $1961,{ }^{19}$ was in force in $1963,{ }^{20}$ when Congress at last turned its attention to the problem of employment discrimination.

\section{B. The Authority for the Executive Orders}

Article II of the Constitution, which defines the powers of the executive branch of the federal government, contains only two passages that suggest any authority for the nondiscrimination programs instituted by the executive orders of President Roosevelt and his successors that culminated in the Philadelphia Plan. First, the President's oath of office requires him to "preserve, protect, and defend the Constitution of the United States."21 It would seem, however, that this provision could be deemed to provide a constitutional basis for an independent exercise of executive power in this area only if: (1) government con-

and Pasley, The Nondiscrimination Clause in Government Contracts, 43 VA. L. REv. 837 (1957).

17 Note, The Philadelphia Plan: Equal Employment Opportunity in the Construction Trades, 6 Colum. J.L. \& Soc. Prob. 187, 194 (1970).

18 Comm. on Government Contracts, Pattern for Progress: Final Report to PresiDENT EISENhower 14 (1960). The Committee stated that it was not so much "overt discrimination" as "the indifference of employers to establishing a positive policy of nondiscrimination that hinders qualified applicants and employees from being hired and promoted on the basis of equality." Id. (emphasis in original). See also 3 U.S. Comm'N on CIVIL RIGHTS, REPORT 76 (1961).

19 Exec. Ordex No. 10,925, 3 G.F.R. 443 (1959-63 Comp.), 5 U.S.C. § 3301 (1970).

20 Exec. Order No. 11,114, 3 C.F.R. 774 (1959-63 Comp.), 5 U.S.G. $\$ 3301$ (1970).

21 U.S. CoNST. art. II, § 1, cl. 7. 
tracting with employers who discriminate violates the Constitution; (2) Congress has failed to provide any means for meeting this problem; and (3) Congress has not disapproved the means chosen by the President to deal with it.

It has been argued that government contracting with known dis. criminators constitutes a violation of the due process clause of the fifth amendment ${ }^{22}$ and that this is sufficient to justify the imposition of the Philadelphia Plan's requirements. ${ }^{23}$ This argument is, however, misguided. The concept of state action has been expanded in the direction of finding state involvement in what was once considered purely private conduct; ${ }^{24}$ but the obligation of the federal government under the fifth amendment to remedy the present effects of past discrimination has not expanded accordingly, or, at least, has not expanded so far as to require the government to insist on preferential hiring of minorities by private parties contracting with it. ${ }^{25}$ This distinction can perhaps be

22 U.S. CoNST. amend. V.

23 Statement of Jerris Leonard, Assistant Attorney General, Givil Rights Division, in Hearings on the Philadelphia Plan and S. 931, supra note 8, at 94-95, 101. For the doctrinal development of this concept, see Comment, The Constitutionality of "Affrmative Action" to Integrate Construction Trades: The Philadelphia Plan, 43 TEMP. L.Q. 329, $332-35,339-40,345-46$ (1970).

24 See Reitman v. Mulkey, 387 U.S. 369 (1967); Burton v. Wilmington Parking Authority, 365 U.S. 715 (1961); Todd v. Joint Apprenticeship Comm., 223 F. Supp. 12 (N.D. Ill. 1963), vacated as moot, 332 F.2d 243 (7th Cir. 1964), cert. denied, 380 U.S. 914 (1965); cf. Gautreaux v. Romney, 448 F.2d 731 (7th Cir. 1971); Simkins v. Moses H. Cone Memorial Hospital, 323 F.2d 959 (4th Cir. 1963), cert. denied, 376 U.S. 938 (1964).

25 A great deal of case law has developed under section 703(h) of Title vII of the 1964 Civil Rights Act, generally to the effect that seniority systems, referral practices, and admissions and promotion criteria that tend either to perpetuate past discrimination or to chill the exercise of newly acquired Title VII rights are impermissible. Only an "overriding business necessity" can justify erecting any barriers to a minority worker's achievement of an employment status commensurate with his skills and (nondiscriminatorily computed) seniority. See, e.g., Griggs v. Duke Power Co., 401 U.S. 424 (1971) (holding that academic and testing requirements must be job-related); United States v. Bethlehem Steel Corp., 446 F.2d 652 (2d Cir. 1971) (overturning departmental seniority system and requiring plantwide seniority and rate retention guarantees for minority employees seeking transfers from formerly segregated department); Heat \& Frost Insulators Local 53 v. Vogler, 407 F.2d 1047 (5th Cir. 1969) (holding illegal nepotism and voting requirements for union membership, and eliminating priority referral system based on union experience where minority workers had been barred from acquiring such credentials). This desire to minimize the present effects of past discrimination has not led to a similar development under section $703(j)$ of the Act. Thus, for example, the remedies imposed for past discrimination have generally not included preferential treatment for previously disadvantaged groups. For an excellent discussion of this issue, see United Papermakers Local 189 v. United States, 416 F.2d 980, 987-98 (5th Gir. 1969). See also notes 189-90 infra. None of these developments, of course, goes directly to the question whether there is a duty on the part of the government to compel those with whom it contracts to engage in compensatory recruitment, training and hiring programs. But they are obliquely relevant, for if such duties cannot be imposed on discriminators directly, 
clarified by reference to the recent decision in Gautreaux $v$. Romney. ${ }^{26}$ In that case, the Seventh Gircuit held that the transfer of federal funds to a local agency known to be engaging in racial discrimination constituted a violation of the fifth amendment. As the court in Gautreaux suggested, it is clearly legal for a contracting agency to suspend federal funding for a project conducted in a discriminatory fashion and to continue the suspension until it is satisfied that past discriminatory practices have ceased. ${ }^{27}$ The decision does not, however, serve to justify the affirmative action approach of the Philadelphia Plan. ${ }^{28}$ It is one thing to say that the government may not, consistently with the fifth amendment, continue to fund discriminatory programs, but quite another to say either that the executive may, by unilateral action, impose on government contractors any requirements that it chooses in order to alleviate the effects of discrimination, or that it is impelled by its constitutional duty to do so.

In addition, the Civil Rights Act of 1964 gave the President potent weapons to deal with the very types of discriminatory activities at which the Philadelphia Plan was aimed. ${ }^{29}$ Since Congress has specifically supplied one remedy, it does not seem reasonable that the President should remain free to choose another simply because he finds it more expedient. While Congress cannot, by legislation, alter the executive's constitutional responsibilities, it has the power to designate the means that he may use to discharge them. Congress did precisely this in Titles

it is certainly questionable that the government would violate the fifth amendment if it did not insist on such conditions.

26448 F.2d 731 (7th Gir. 1971). See also Hicks v. Weaver, 302 F. Supp. 619 (E.D. La. 1969) (holding HUD liable on virtually identical facts).

27 See 448 F.2d at 732, 737-40. It is noteworthy, however, that the Seventh Circuit did not feel that such a remedy was compelled, even though it had found the Secretary's previous conduct to be illegal:

[O]ur holding should not be construed as granting a broad license for interference with the programs and actions of an already beleaguered federal agency. It may well be that the District Judge ... will conclude that little equitable relief above the entry of a declaratory judgment and a simple "best efforts" clause will be necessary to remedy the wrongs which have been found to have been committed.

Id. at 740-41. Moreover, when the district judge decided that sterner measures were necessary, Gautreaux v. Romney, 332 F. Supp. 366 (N.D. IIl. 1971), he was reversed, 457 F.2d 124 (7th Gir. 1972).

28 For a description of the Plan's affirmative action requirements, see text and notes at notes 91-108 infra.

29 The unions' discriminatory activities and those of related apprenticeship programs are reached by section 703(c)-(d) of Title VII. 42 U.S.C. $\$ \S 2000$ e-2(c)-(d) (1970). Nor need the executive wait for private complainants to remedy the situation. Instead, the Attorney General may initiate a "pattern or practice" suit under section 707(a), 42 U.S.C. 2000e-6(a) (1970), in which he may seek "such relief . . . against the person or persons responsible for such pattern or practice as he deems necessary to insure the full enjoyment of the [Title VII] rights herein described." Id. 
VI and VII of the 1964 Act, and, as the discussion below will demonstrate, the requirements of the Philadelphia Plan are clearly inconsistent with this legislation. Thus, it is difficult to credit the executive's plea that the Philadelphia Plan was instituted as a matter of constitutional necessity.

The other possible constitutional source of the President's power to institute the Philadelphia Plan is the mandate in article II, section 3 that "[the President] shall take care that the Laws be faithfully executed."30 In Myers v. United States, Mr. Justice Holmes succinctly described the scope of this duty: "[It] does not go beyond the laws or require him to do more than Congress sees fit to leave within his power." 31 The possible sources of statutory authority for the executive order program are, however, few in number and, upon close examination, none of them appears at all relevant to the problem of employment discrimination. Even the most adventuresome commentators have been unable to unearth the statutes upon which President Roosevelt claimed to have based his antidiscrimination orders; but an act passed subsequently has been used to justify the continued administration' of the executive program. Section 205 of the Federal Property and Administration Services Act of $1949^{32}$ is a clear grant of authority to the President to issue executive orders. This power is, however, restricted to those orders "necessary to effectuate the provisions of said Act." 33 Two questions are therefore presented. First, what were the purposes of the Act? And second, are any of these purposes sufficiently related to the problem of employment discrimination by government contractors to constitute authority for executive orders to deal with it? The legislative history of the Act clearly indicates that its purpose was to make government procurement more efficient and economical, and that the inefficiencies with which Congress was concerned-such as poor inventory management-were in no way related to racial discrimination. ${ }^{34}$

30 U.S. ConsT. art. II, $\S 3$.

31272 U.S. 52, 177 (1926) (dissenting opinion). Justice Holmes's view was vindicated in Humphrey's Ex'r v. United States, 295 U.S. 602 (1935).

3240 U.S.C. $\$ \S 471$ et seq. (1970).

3340 U.S.C. $\$ 486$ (a) (1970).

34 See U.S. Code Cong. Serv. 1475-76 (1949):

[T] he bill [was intended] to simplify the procurement, utilization, and disposal of Government property, ...

The framework of this Iegislation establishes a General Service Administration, headed by an Administrator, answerable directly to the President, who would concern himself with the procurement, utilization and disposal of Government property. In this way, great strides can be made in increased efficiency and economy of operation by the Federal Government. "The essential foundation of management standards in determining what and what quantities should be bought, and similar standards to govern utilization are conspicuous by their absence.... [This results in] excessive 
Although it is beyond dispute that this Act was aimed at problems of internal administration in the executive departments, it has nevertheless been viewed in two cases as the sole statutory authority for the executive employment discrimination orders. In neither case, however, was the statutory authority for the orders in contention. In Farmer $v$. Philadelphia Electric Co., ${ }^{35}$ the plaintiff alleged that he had been dismissed because of racial discrimination. His complaint was based on the theory that he was a third party beneficiary of nondiscrimination clauses in contracts between the defendant contractor and the federal government. $^{36}$ The defendant's chief contention was that the extensive administrative apparatus set up to deal with such complaints manifested a clear intention of the executive not to confer a private right of action on aggrieved parties. Thus the defendant did not oppose directly the executive's authority to issue the order ${ }^{37}$ or the plaintiff's claim to some relief under the order. Instead it argued merely that the plaintiff should submit his grievance to the cumbersome administrative apparatus that the order contemplated. In sustaining the defendant's position, ${ }^{38}$ the court apparently accepted the view that the orders were issued pursuant to section 205, and therefore had the force of law, without considering the true purpose of the statute. ${ }^{39}$

In Farkas $v$. Texas Instrument, Inc., ${ }^{40}$ the court seems to have perceived the difficulties that inhere in viewing section 205 as statutory authority for the executive order program, but it failed to deal with them. In Farkas, as in Farmer, a discharged employee sought relief in federal court, alleging that the defendant had dismissed and subsequently refused to rehire him because of his national origin, in violation of nondiscrimination clauses in the defendant's federal contracts. ${ }^{41}$ Again, the defendant contended only that the aggrieved employee should be required to exhaust his administrative remedies, and once again, this defense prevailed. The court's discussion of the authority for Executive Order No. 10,925 and its predecessors was confined

stocks, unnecessary duplication, [and] lack of maximum utilization ... [citation omitted]."

35329 F.2d 3 (3d Cir. 1964).

36 These clauses were required by Exec. Order No. 10,925, 3 C.F.R. 443 (1959-63 Comp.), 5 U.S.C. $\$ 3301$ (1970).

37 The court's discussion of the legality of the order strongly suggests that defendant let this point go by default. $329 \mathrm{~F} .2 \mathrm{~d}$ at $7-8$.

38 Id. at 9-10.

39 The court did note that arguments against the legality of the executive order program had been adduced in the literature, but dismissed them out of hand. Id. at $8 \mathrm{n} .9$. 40375 F.2d 629 (5th Gir. 1967).

41 Again, the executive order requiring these clauses was No. 10,925, 3 G.F.R. 443 (1959-63), 5 U.S.C. $§ 3301$ (1970). 
to a footnote: "We would be hesitant to say that the antidiscrimination provisions of Executive Order No. 10925 are so unrelated to the establishment of 'an economical and efficient system for ... the procurement and supply' of property and services, 40 U.S.G.A. $\$ 471$, that the order should be treated as issued without statutory authority." 42 Absent a demonstration of the executive order's relation to the purposes of the statute, it seems clear that the court's hesitancy was unwarranted. ${ }^{43}$

A third and apparently quasi-constitutional source of authority that has been claimed for the executive order program is the "right of the government to decide with whom and upon what conditions it will do business." 44 There is not now, and probably never has been, a "right of the government" as unlimited as this formulation would imply. The government cannot, of course, impose unconstitutional conditions. ${ }^{45}$ But, short of constitutional limitations, there remains the question whether the executive can, by means of executive orders, impose contractual conditions without statutory authorization. Perkins v. Lukens Stee $l^{ \pm 6}$ has been cited for the existence of that power, with particular emphasis on the following language: "Like private individuals and business, the Government enjoys the unrestricted power to produce its own supplies, to determine those with whom it will deal, and to fix the terms and conditions upon which it will make needed purchases." 47 In fact, however, Lukens Steel did not deal with the question of the authority of the executive branch to determine contractual conditions. First, the executive action challenged in the case was taken under the authority of a statute, not an executive order. Second, the Court used the term Government in the case to refer, not to the executive branch, but to Congress. ${ }^{48}$ Finally, the only issue addressed in

42375 F.2d at 632 n.1.

43 Justice Frankfurter's concurring opinion in Youngstown Sheet \& Tube Co. v. Sawyer, 343 U.S. 579 (1952), deals explicitly with an attempt by the executive to strain an irrelevant grant of statutory authority to cover its challenged exercise of power. Such distortions, said Frankfurter, were not permissible: "In considering the Defense Production Act Amendments, Congress was never asked to approve-and there is not the slightest indication that the responsible committees ever had in mind-seizure of plants to coerce settlement of disputes. . . . To draw implied approval of seizure power from this history is to make something out of nothing." Id. at 608-09 (concurring opinion).

44 Jones, supra note 8, at 383 .

45 See, e.g., Gonzalez v. Freeman, 334 F.2d 570, 574 (D.C. Cir. 1964); Copper Plumbing \&. Heating Co. v. Campbell, 290 F.2d 368, 371 (D.C. Cir. 1961). In each case the court held that the Government may not arbitrarily assert its power so as to deny a contractor the opportunity to bid.

40310 U.S. 113 (1940).

47 Id. at 127.

48 The Court did say that had the Secretary violated congressional instructions, she was responsible only to "superior executive and legislative authority." Id. at 129. But 
Lukens Steel was whether the contractor had standing to challenge the legality of terms in its contract with the government. The Court held that it did not, but this is almost certainly no longer the law. ${ }^{49}$

The legality of the Philadelphia Plan was challenged in Contractors Association v. Secretary of Labor.50 In its opinion, the Third Circuit seems to have recognized the inadequacy of both the Farmer-Farkas and Lukens Steel rationales as bases for the assertion of executive power to implement the Plan. The court, nevertheless, sustained the Plan: "When the Congress authorizes an appropriation for a program of federal assistance, and authorizes the Executive branch to implement the program by arranging for assistance to specific projects, in the absence of specific statutory regulations it must be deemed to have granted to the President a general authority to act for the protection of federal interests." 51 The court found that the federal interest protected by the Plan was financial, since "exclusion from the available labor pool of minority tradesmen is likely to have an adverse effect upon the cost and completion of construction projects ...." "'52

The court's analysis is too facile. It fails to deal with the central separation of powers issues that the Philadelphia Plan presented: May Congress, by legislation, define the scope of federal interests and, more importantly, prescribe and thereby limit the appropriate means for their vindication? If so, did Congress do exactly this in the fair employment field when it enacted the Civil Rights Act of 1964?

\section{The Givil Rights Act of 1964 ANd Its Impact on the Executive Order Program}

The Civil Rights Act of $1964^{53}$ contains a broad program to attack the evils of discrimination in employment. Titles VI and VII of the Act deal specifically with acts of employment discrimination based on race, religion, color, national origin, or sex. Title VI applies to employers operating under federally assisted government contracts. Section $602^{54}$ directs each federal agency authorized to extend such federal assistance to promulgate rules and regulations to explain how it will

that phrase is no longer the law. See Barlow v. Collins, 397 U.S. 159 (1970) (upholding standing of party to seek judicial review of regulation promulgated by Secretary of Agriculture). More importantly, the Court's statement concerned a situation very different from one in which the executive acts without any kind of statutory authority.

49 See Scanwell Laboratories, Inc. v. Shaffer, 424 F.2d 859 (D.G. Cir. 1970).

50442 F.2d 159, 166-67 (3d Cir. 1971).

51 Id. at 171 .

52 Id. at 175 .

5342 U.S.C. $\$ \$ 2000 \mathrm{a}$ et seq. (1970).

54 Id. $\$ 2000 \mathrm{~d}-1$ (1970). 
enforce the Act's antidiscrimination mandate. The general scheme of Title VI couples this broad initial delegation of authority to the agencies with tight supervisory control by Congress over the programs that the agencies were to develop. ${ }^{55}$

While Congress was reluctant to leave the various agencies completely free under Title VI to formulate their own programs to combat discrimination in employment, under the provisions of Title VII it made employment discrimination unlawful, whether committed by employers, ${ }^{56}$ employment agencies, ${ }^{57}$ labor organizations, ${ }^{58}$ or in training programs. ${ }^{50}$ This demonstrates that Congress was aware of the wide range of discriminatory employment practices then current, and that the Act was not a short-sighted, stopgap measure, but rather a comprehensive piece of legislation designed to provide a means of attacking, by court action, any party who engaged in discriminatory conduct.

Congress was also aware that yesterday's discrimination leaves its mark on today's employees. The most difficult problem involved in the formulation of Title VII's judicial remedies was defining the scope of activities an employer or other discriminating party could be required to undertake to remedy the present effects of past discriminatory acts. On the one hand, it was felt that it would be unjust to freeze a whole generation of employees into the inequitable position created by past illegal actions. Thus, in section $706(\mathrm{~g})$, Congress provided that:

If the court finds that the respondent has intentionally engaged in or is intentionally engaging in an unlawful employment practice charged in the complaint, the court may enjoin the respondent from engaging in such unlawful employment practice, and order such affirmative action as may be appropriate, which may include reinstatement or hiring of employees, with or without back pay $\ldots 0^{60}$

On the other hand, opponents of the bill feared that it would authorize the imposition of quotas of minority workers on employers. ${ }^{61}$ They also feared that courts would view merit hiring, merit promotion, and existing seniority systems as merely devices locking in past discrimina-

55 The question whether the Philadelphia Plan is consistent with Title VI is discussed in the text at notes 110-116 infra.

6642 U.S.C. \& 2000e-2(a) (1970).

57 Id. § 2000e-2(b) (1970).

58 Id. $\$ 2000 \mathrm{e}-2$ (c) (1970).

$59 \mathrm{Id}$. $\$ 2000 \mathrm{e}-2$ (d) $(1970)$.

60 Id. $\$ 2000 \mathrm{e}-5(\mathrm{~g})(1970)$.

61 See, e.g., 110 Cong. Rec. 5877-78 (1964) (remarks of Senator Byrd); id. at 7774, 7778 (1964) (remarks of Senator Tower). 
tory practices and would, therefore, forbid them. ${ }^{62}$ The sponsors of the Act repeatedly denounced such charges as irresponsible; they contended that racial quotas were not only unintended by the Act but, in fact, illegal under it. ${ }^{63}$ The floor managers of the legislation in the Senate, Senators Clark and Case, left no doubt as to how they felt Title VII dealt with these issues:

There is no requirement in title VII that an employer maintain a racial balance in his work force. On the contrary, any deliberate attempt to maintain a racial balance, whatever such a balance may $b e$, would involve a violation of title VII because maintaining such a balance would require an employer to hire or to refuse to hire on the basis of race. It must be emphasized that discrimination is prohibited as to any individual. ${ }^{04}$

The concern of Congress on this score resulted in the inclusion in Title VII of section 703(j):

Nothing contained in this subchapter shall be interpreted to require any employer, employment agency, labor organization, or joint labor-management committee subject to this subchapter to grant preferential treatment to any individual or to any group because of the race, color, religion, sex, or national origin of such individual or group on account of an imbalance which may exist with respect to the total number or percentage of persons of any race, color, religion, sex, or national origin employed . . . in comparison with the total number or percentage of [such] persons ... in any $\ldots$ area, or in the available work force in any ... area. ${ }^{65}$

62 To prevent this, Senator Allott introduced an amendment providing:

The court shall not find, in any civil action brought under this title, that the respondent has engaged in or is engaging in an unlawful employment practice charged in the complaint solely on the basis of evidence that an imbalance exists with respect to the total number or percentage of persons of any race, color, religion, sex, or national origin employed by any employer, ... without supporting evidence of another nature that the respondent has engaged in or is engaging in such practice. Id. at 9881-82 (1964). The amendment was not adopted.

63 See, e.g., id. at 6549 (1964) (remarks of Senator Humphrey).

64 Id. at 7213 (1964) (emphasis added). See also id. at 7207 (1964) (remarks of Senator Clark) (emphasis added): "Finally it has been asserted Title VII would impose a requirement for 'racial balance.' This is incorrect. There is no provision, either in Title VII or in any other part of this bill, that requires or authorizes any Federal agency or Federal court to require preferential treatment for any individual or any group for the purpose of achieving racial balance."

6542 U.S.C. $\S 2000 \mathrm{e}-2(\mathrm{j})(1970)$. Also pertinent is section $703(\mathrm{~h})$, 42 U.S.C. $\S 2000 \mathrm{e}-2(\mathrm{~h})$ (1970), which provides in part:

Notwithstanding any other provision of this subchapter, it shall not be an unlawful employment practice for an employer to apply different standards of compensation, or different terms, conditions, or privileges of employment pursuant to a bona fide seniority or merit system, or a system which measures earnings by quantity or quality of production or to employees who work in different locations, provided that such differences are not the result of an intention to discriminate because of race, color, religion, sex, or national origin, nor shall it be an unlawful employment practice for an employer to give and to act upon the results of any professionally developed 
Proponents of the Philadelphia Plan have made much of the fact that this section states only that Title VII did not require preferential treatment, and does not say that preferential treatment was not permitted. They read the "not required" language as indicating congressional approval of, or at least acquiescence in, the imposition of such a requirement by other arms of government, and, hence, an implicit authorization for an affirmative action program like that adopted by the Department of Labor. ${ }^{68}$

But this reasoning seems incorrect. First, if Congress had absolutely banned preferential hiring in section $703(\mathrm{j})$, it would have flatly contradicted its explicit authorization of such relief in section $706(\mathrm{~g})^{67}$ when a court found it necessary to remedy discriminatory practices. This, by itself, is perhaps a sufficient explanation of the language in section $703(j)$. In addition, although the "not required" language is confined to "this subchapter," this was no limitation at all when the legislation was enacted, since the subchapter created the only federal relief then available for discrimination in employment. There was no other federal legislation on the subject and the executive order program had never imposed quotas or preferential hiring requirements. ${ }^{68}$ If the language must be given further significance, it can be interpreted as indicating

ability test provided that such test, its administration or action upon the results is not designed, intended or used to discriminate because of race, color, religion, sex or national origin.

This section has suffered a good deal at the hands of the courts. Its restrictive language has been drastically curtailed by obliging it to give way to the affirmative relief authorized by $\S 706(\mathrm{~g})$. See, e.g., Griggs v. Duke Power Co., 401 U.S. 424 (1971) (requiring ability test to be job-related); United States v. Sheet Metal Workers Local 36, 416 F.2d 123 (5th Cir. 1969) (requiring that black applicants be awarded positions on the basis of plantwide rather than departmental seniority where they had been locked out of all-white lines of progression). This judicial hostility may extend to section 703(j) as well and account in part for the courts' general acceptance of Philadelphia Plan requirements. See Contractors Ass'n v. Secretary of Labor, 442 F.2d 159 (3d Cir. 1971) (affirming legality of Philadelphia Plan). Compare United States v. Ironworkers Local 86, 443 F.2d 544 (9th Cir. 1971), aff'g 315 F. Supp. 1202 (W.D. Wash. 1970) (imposing quota on intake for apprenticeship program) with Dobbins v. Local 212, IBEW, 292 F. Supp. 413, 445 (S.D. Ohio 1968) (no such obligation is permitted under Title VII). For a discussion of these developments, see text and notes at notes 163-67, 184 \& 190 infra.

66 See generally authorities cited note 8 supra, first paragraph.

67 See text and note at note 60 supra.

08 As the Comptroller General said in his opinion declaring the Philadelphia Plan illegal:

[W] hile the phrase "affirmative action" was included in the executive order (10925), which was in effect at the time Congress was debating the bills which were subsequently enacted as the Civil Rights Act of 1964, no specific affirmative action requirements of the kind here involved had been imposed upon contractors under authority of that Executive Order at that time, and we therefore do not think it can be successfully contended that Congress, in recognizing the existence of the executive order and in failing to specifically legislate against it, was approving or ratifying the type or methods of affirmative action which ... [the Labor Department] now proposes to impose upon contractors.

49 Comp. Gen. 59, 70-71 (1969). 
that Congress did not intend to limit the states' power to impose such requirements if they wished. ${ }^{69}$ Finally, it is fundamentally inconsistent with the constitutional division of authority between the legislative and executive branches to require Congress to forbid executive action explicitly before the executive can be deemed foreclosed from acting in a manner contrary to a policy that Congress has expressed in a com. prehensive legislative scheme. ${ }^{70}$

In any case, the legislative history of Title VII indicates that, in fact, Congress did explicitly disapprove such executive action. As the 1964 Act wended its way through Congress, two significant attempts to amend it were made. The first was an amendment submitted by Senator Tower, which provided, in substance, that Title VII was to be the exclusive federal remedy for discrimination in employment, thus ousting the President from the field..$^{71}$ The defeat of this proposal, which is often pointed to by proponents of the Philadelphia Plan, certainly connotes congressional recognition and approval of the executive order program as it was then constituted. But this commendation must be considered substantially qualified by action taken in the House on a radically different proposal. H.R. 7152, which was to become the Civil Rights Act of 1964, initially contained a section 711(b) that provided specific statutory authorization for an executive antidiscrimination program. ${ }^{72}$ In the committee report on H.R. $7152,{ }^{73}$ the majority argued

69 State laws are maintained in full force and effect, except insofar as they purport "to require or permit the doing of any act which would be an unlawful employment practice under this subchapter." 42 U.S.C. \$ 2000e-7 (1970). Arguably, however, this proviso would not allow a state policy of quota hiring or preferential treatment for minorities.

70 Youngstown Sheet \& Tube Co. v. Sawyer, 343 U.S. 579, 609 (1952) (Frankfurter, J., concurring):

It is one thing to draw an intention of Congress from general language and to say that Congress would have explicitly written what is inferred, where Congress has not addressed itself to a specific situation. It is quite impossible, however, where Congress did specifically address itself to a problem, ... to find secreted in the interstices of legislation the very grant of power which Congress consciously withheld. To find [here] authority so explicitly withheld is .... to disrespect the whole legislative process and the constitutional division of authority between President and Congress.

71 This amendment, in relevant part, read as follows: "[T] he provisions of this title shall constitute the exclusive means whereby any department, agency, or instrumentality in the executive branch of the Government . . . may grant or seek relief from, or pursue any remedy with respect to, any employment practice ... covered by this title, if such employment practice may be the subject of a charge or complaint filed under this title." 110 Cong. REc. 13,650 (1964). The amendment was rejected. Id. at 13,652.

72 The proposed section 711(b) provided: "The President is authorized to take such action as may be appropriate to prevent the committing or continuing of an unlawful employment practice by a person in connection with the performance of a contract with an agency or instrumentality of the United States." H.R. REP. No. 914, 88th Cong., 1st Sess., pt. 2 (Judiciary Comm. 1963), in U.S. EQual EMployment Opportunity Comm'N, Leg. Hist. OF TIrLES VII AND XI OF THE CrVIL Rughts Acr OF 1964, at 2014.

73 Id. at 2001. 
that a statutory foundation for executive action would prevent revocation or modification of the program by future Presidents, and that "any doubt about the validity of promulgating such far-reaching national policy by Presidential action not founded upon any statutory grant of authority would be removed."74 The minority report, ${ }^{75}$ however, contended that H.R. 7152 granted "new, sweeping and unlimited authority to the President." It continued: "The pending bill has strengthened and broadened the enforcement provisions by giving the President blanket and unlimited authority (sec. $711(\mathrm{~b})$ ), which was not contained in the subcommittee proposal."'76

With this as background, the following segment of debate on an amendment by Representative Celler deleting section 711 is most significant:

Mr. PoFf. ... The adoption of this amendment ... would in no wise affect substantive law as it is written on the books today.

Mr. Celler. And will the gentleman not also say that the deletion of the language by the amendment does not have any effect upon existing Presidential power.

MR. Poff. Of course, the striking of language from a bill could not in any way impair existing law.

Mr. Gerler. And it does not limit it and it does not broaden it. It remains intact as it is now.

Mr. Poff. That is true.

Mr. CeLler. Mr. Chairman. I join in support of this amendment. ${ }^{77}$

A compromise was thus struck between the supporters and the opponents of the civil rights legislation. The opponents objected to section 711(b), and that language was deleted; but the existing power of the President was not affected. It can, therefore, be inferred that Congress did not intend to authorize the President to institute whatever new executive program he might think appropriate. While no presidential power was taken away, Congress gave the President no latitude to develop new methods to attack discrimination by employers under federal contract.

In debates concerning the legality of the Philadelphia Plan, it has often been pointed out that, in passing the 1964 Givil Rights Act, Congress implicitly recognized the existence of the executive order program, including the affirmative action requirements that it then 
contained, and approved its continuation. ${ }^{78}$ This position is undoubtedly correct, ${ }^{79}$ but too much has been made of it. Particularly since its approval was only tacit, Congress can be taken to have ratified only the executive program then in existence.

What kinds of affirmative action by employers did the executive program then in force require? While the obligations imposed on federal contractors were not entirely clear, apparently they involved efforts to inform minority group workers of employment opportunities ${ }^{80}$ and to recruit minority employees into existing, on-the-job manpower training programs. ${ }^{81}$ The emphasis was not so much on remedial programs as on gaining adequate information about the aptitudes of minority workers so that employers could make neutral hiring and promotion decisions. There were no goal or quota requirements even implicit in the program, and no penalty was imposed for failure to progress, in terms of the percentage of minority workers employed, at some set rate. ${ }^{82}$ Employers were required by the program to bear only certain costs necessary to ascertain the qualifications of minority workers for employment and promotion, ${ }^{83}$ and even these requirements were generally unenforced..$^{84}$

In sum, Titles VI and VII of the 1964 Act represented a comprehen-

78 See, e.g., Jones, supra note 8, at 392-94.

79 One provision pointed to is $\$ 709$ (d), 42 U.S.C. $\$ 2000 \mathrm{e}-8$ (d) (1970):

Where an employer is required by Executive Order 10925 ... or by any other Executive order prescribing fair employment practices for Government contractors and subcontractors, or by rules or regulations issued thereunder, to file reports relating to his employment practices with any Federal agency or committee, and he is substantially in compliance with such requirements, the Commission shall not require him to file additional reports pursuant to subsection (c) of this chapter.

But this language expresses congressional approval only of the registration and filing procedures adopted by various agencies, not the substantive content of their antidiscrimination programs. A second section frequently cited in this regard is section 1103, 42 U.S.C. \$ 2000h-3 (1970): "Nothing in this Act shall be construed to deny, impair, or otherwise affect any right or authority of the Attorney General or of the United States or any agency or officer thereof under existing law to institute or intervene in any action or proceeding." Id. (emphasis added). While this language is ambiguous, it appears to militate against expansions as well as contractions of executive power. The correctness of this reading emerges clearly from the legislative history of the Act. See text at notes 71-79 supra.

80 See Note, Executive Order 11,246: Anti-Discrimination Obligation in Govermment Contracts, 44 N.Y.U.L REv. 590, 593 (1969), which points out that early attempts to administer Executive Order No. 10,925 emphasized advertising and a broadening of the recruitment base.

81 Id. at $593-94$.

82 Professor Fiss thinks that this basic approach was Ieft intact under Title VII and, arguably, under Executive Order No. 11,246 as well. Fiss, supra note 8, at 311-12.

83 Ñote, supra note 80 , at 593-96.

84 Note, The Philadelphia Plan: Equal Employment Opportunity in the Construction Trades, 6 Colum. J.L. \& Soc. Prob. 187, 194-95 (1970). 
sive statutory scheme to deal with the problem of racial discrimination in employment. This legislation rejected the imposition of quotas or preferential hiring requirements as a means of meeting the employment problems that minority workers face. Congress examined the program that the executive branch had instituted to deal with employment discrimination by federal contractors and specifically rejected efforts either to eliminate it or to authorize its expansion beyond its then existing scope. It was in this setting that the Philadelphia Plan was implemented.

\section{The Philadelphia Plan: Does It Conflict with the Civil Rights Act of 1964?}

\section{A. The Philadelphia Plan}

Shortly after the effective date of the Civil Rights Act of 1964, Executive Order No. 11,246 was issued, requiring federally assisted construction contractors and their subcontractors to afford equal employment opportunity if they desired to do business with the federal government. $^{85}$ To help implement this requirement, the Office of Federal Contract Compliance (OFCG) established a system of area coordinators to develop government-wide compliance programs for the construction industry in particular labor market areas. ${ }^{86}$ For the Philadelphia metropolitan region, the OFCG developed the Philadelphia Pre-Award Plan. Under this plan the apparent low bidder on each federally assisted contract was required to submit an acceptable affirmative action program for the employment of minority workers before it could be awarded the contract. ${ }^{87}$ The Plan did not outline definite minimum requirements for minority employment, nor did it detail the criteria by which acceptability would be ascertained. ${ }^{88}$ If a low bidder's proposed program was found unacceptable, the Plan provided for a preaward conference to negotiate an acceptable revision.

This program created a considerable amount of dissatisfaction in the industry, and Congressman William Cramer requested an opinion from the Comptroller General as to whether the procedures comported

85 Exec. Order No. 11,246, 3 C.F.R. 339 (1964-65 Comp.), 42 U.S.C. § 2000e (1970), as amended by Exec. Order No. 11,375, 3 C.F.R. 684 (1966-70 Comp.), 42 U.S.C. \& 2000e (1970) (sex discrimination) and Exec. Order No. 11,478, 3 C.F.R. 803 (1966-70 Comp.), 42 U.S.C. $\S 2000 \mathrm{e}$ (1970) (government employment), is set out at 3 C.F.R. 402 (1970), 42 U.S.C. $\S 2000 \mathrm{e}(1970)$. The covenants to which the contractor agrees are contained in section 202.

86 Jones, supra note 8 , at 343 .

8748 COMP. GEN. 326, 327 (1968).

88 This lack of criteria was intended to allow "the utmost in creativity, ingenuity, and imagination." $I d$. 
with the federal government's traditional requirement of competitive bidding. The Comptroller General found that they did not, ${ }^{89}$ but he did not suggest that affirmative action programs like those required of contractors under the Plan were impermissible under Title VII. On the contrary, according to him, the sole vice of the procedure was its lack of standards, and this could be easily remedied by "informing prospective bidders of definite minimum requirements to be met by the bidder's program and any other standards or criteria by which the acceptability of such programs would be judged."90 The opinion thus gave no clue that the Comptroller General would find a plan with definite standards equally objectionable.

The Department of Labor thereupon attempted to meet the objec. tions made by the Comptroller General to the Pre-Award Plan. The central feature of the revised Philadelphia Plan was a requirement that contractors submit a statement of "goals" of minority employment together with their bids. ${ }^{91}$ These goals were to fall within a "range" set by the government, ${ }^{92}$ which was supposedly arrived at by examining four factors: (1) the current extent of minority group participation in the trade; (2) the availability of minority group persons for employment in such trade; (3) the need for training programs in the area and/ or the need to assure demand for those in existing training programs; and (4) the impact of the program on the existing labor force. ${ }^{93}$

An effort to meet the strictures of Title VII was apparent as well. The Plan was prefaced by findings of discrimination in the construction trades, like those that a court must make to grant relief under Title VII. ${ }^{94}$ In contrast, however, to a judicial determination of discrimination, the finding in the Plan implicated not the contractors upon whom the requirements were imposed, but, instead, the unions of the employees who worked for them. ${ }^{95}$

The major source of conflict anticipated between Title VII and the Plan was the possibility that the minority employment goals would

89 The opinion stated:

No prospective contractor can intelligently compute his bid, or even decide that he wishes to incur the expenses of competing for the contract, without being fully informed before hand of all factors which will materially affect the cost of his work or his ability to perform .... Further, where material conditions and requirements are not clearly defined, such circumstances give rise to the opportunity for favoritism, arbitrary action and abuse of authority in the awarding ... of the contracts.

Id. at 328.

$90 I d$.

91 Text of Plan, supra note $5, \S 4$.

$92 \mathrm{Id}$. 5 .

93 Id. $\$ 6(\mathrm{c})$.

94 Id. \& 4.

95 Id. § 4. 
be construed as quotas and would, therefore, be impermissible under section 703(j). To avoid this result, the Plan required employers only to exert a "good faith effort" to reach the goals, rather than actually to attain them. ${ }^{96}$ The Plan also stated that "[t]he purpose of the contractor's commitment to specific goals is to meet the contractor's affirmative action obligations and is not intended and shall not be used to discriminate against any qualified applicant or employee."'97 These two escape valves were, however, of little consolation to contractors. The Plan went on to provide that it was not an excuse that the unions with which they had collective bargaining agreements failed to refer minority employees; contractors could not escape their affirmative action obligations by "delegating the responsibility for some of their employment practices to some other organization."98 Thus, contractors that had exclusive hiring hall arrangements with unions ${ }^{99}$ were faced with a difficult choice: they could either violate the arrangements or be unable to comply with the Plan's requirements.

The precise scope of the contractor's obligations was not revealed when the Plan was first issued. ${ }^{100}$ Apparently, the Department of Labor had not at that time determined the degree to which there had been employment discrimination in the construction crafts and it was, therefore, not prepared to establish the ranges within which the contractor's goals had to fall. The necessary investigations were completed and a Supplemental Order issued by the Assistant Secretary of Labor on September 23, 1969.101 In brief, this order reaffirmed the earlier finding of discrimination, noting that only 1 percent of the employees in the trades covered by the Plan were nonwhite. This figure was considered too insignificant to affect the range in any way. ${ }^{102}$ The report found that a "substantial" number of qualified minority work-

96 Id. $\S 8(\mathrm{a})$. This, of course, was no help to a contractor who honestly believed at the time of placing his bid that union opposition to his program would make his goals impossible to attain. Such a contractor, it would appear, could not make a good faith commitment to operate at some satisfactory level of minority manpower utilization.

$97 I d . \$ 6(\mathrm{~b})(2)$.

88 Id. \& 8(b). This result seems directly contrary to the result intended by the sponsors of Title VII. In their interpretive memorandum on that legislation, Senators Clark and Case dealt with the problem of discriminatory union referrals as follows: "If the hiring hall discriminates against Negroes and sends [the employer] only whites, he is not guilty of discrimination-but the union hiring hall would be." 110 CoNG. Rec. 7217 (1964).

99 Such agreements were customary in the Philadelphia area.

100 The Department of Labor decreed discrimination first and found it later. Even the most ardent supporters of the Plan have conceded that the reverse sequence of operation would have been a "more orderly" procedure. Jones, supra note 8, at 388 n.249.

101 Implementation Order, supra note 5.

102 Id. § 3(a). 
ers were available for productive employment, although it noted that there was a considerable need for training programs as well. ${ }^{103}$ It then set forth the procedures for establishing the ranges of minority manpower utilization..$^{104}$ On the basis of these calculations it was determined that "a contractor could commit to minority hiring up to the annual rate of job vacancies for each trade without adverse impact on the existing labor force." 105 Therefore, according to the report, it was permissible to establish ranges of minority utilization at somewhat more conservative figures. ${ }^{106}$ "[T] he lower-range figure," the Plan

$103 I d . \S 3(\mathrm{~b})-(\mathrm{c})$.

104 The first step was to figure a yearly attrition rate for each craft, based on the aggregate of departures from it due to death, disability, retirement, and all other reasons. This was found to be 7.5 percent per year for each craft. Then, an average annual growth rate for each craft over the next four years was computed. These figures, ranging from 2.0 percent to 3.7 percent, were added to the departures figure to give annual vacancy rates for each craft, as indicated below.

$\begin{array}{lc}\quad & \begin{array}{c}\text { Annual } \\ \text { Vacancy } \\ \text { Identification of Trade }\end{array} \\ \text { Rate } \\ \text { Ironworkers } & 11.2 \% \\ \text { Plumbers and Pipefitters } & 10.4 \% \\ \text { Steamfitters } & 10 \% \\ \text { Sheetmetal workers } & 9.5 \% \\ \text { Electrical workers } & 9.7 \% \\ \text { Elevator construction workers } & 9.6 \%\end{array}$

Implementation Order, supra note 5, § 3(d).

$105 \mathrm{Id}$.

108 The actual standards adopted are set out below.

\begin{tabular}{|c|c|c|c|}
\hline Identification of Trade & $\begin{array}{l}\text { Range of } \\
\text { Minority } \\
\text { Group Em- } \\
\text { ployment } \\
\text { until } \\
\text { December } \\
\mathbf{3 1}, \mathbf{1 9 7 0}\end{array}$ & Identification of Trade & $\begin{array}{l}\text { Range of } \\
\text { Minority } \\
\text { Group Em } \\
\text { ployment } \\
\text { for the } \\
\text { Calendar } \\
\text { Year } 1971\end{array}$ \\
\hline $\begin{array}{l}\text { Ironworkers } \\
\text { Plumbers \& Pipefitters } \\
\text { Steamfitters } \\
\text { Sheetmetal workers } \\
\text { Electrical workers } \\
\text { Elevator construction workers }\end{array}$ & $\begin{array}{l}5 \%-9 \% \\
5 \%-8 \% \\
5 \%-8 \% \\
4 \%-8 \% \\
4 \%-8 \% \\
4 \%-8 \%\end{array}$ & $\begin{array}{l}\text { Ironworkers } \\
\text { Plumbers \& Pipefitters } \\
\text { Steamfitters } \\
\text { Sheetmetal workers } \\
\text { Electrical workers } \\
\text { Elevator construction workers }\end{array}$ & $\begin{array}{r}11 \%-15 \% \\
10 \%-14 \% \\
11 \%-15 \% \\
9 \%-13 \% \\
9 \%-13 \% \\
9 \%-13 \%\end{array}$ \\
\hline $\begin{array}{l}\quad \text { Identification of Trade } \\
\text { Ironworkers } \\
\text { Plumbers \& Pipefitters } \\
\text { Steamfitters } \\
\text { Sheetmetal workers } \\
\text { Electrical workers } \\
\text { Elevator construction workers }\end{array}$ & $\begin{array}{c}\text { Range of } \\
\text { Minority } \\
\text { Group Em- } \\
\text { ployment } \\
\text { for the } \\
\text { Calendar } \\
\text { Year } 1972 \\
16 \%-20 \% \\
15 \%-19 \% \\
15 \%-19 \% \\
14 \%-18 \% \\
14 \%-18 \% \\
14 \%-18 \%\end{array}$ & \begin{tabular}{l}
\multicolumn{1}{c}{ Identification of Trade } \\
Ironworkers \\
Plumbers \& Pipefitters \\
Steamfitters \\
Sheetmetal workers \\
Electrical workers \\
Elevator construction workers
\end{tabular} & $\begin{array}{c}\text { Range of } \\
\text { Minority } \\
\text { Group Em- } \\
\text { ployment } \\
\text { for the } \\
\text { Calendar } \\
\text { Year } 1973 \\
22 \%-26 \% \\
20 \%-24 \% \\
20 \%-24 \% \\
19 \%-23 \% \\
19 \%-23 \% \\
19 \%-23 \%\end{array}$ \\
\hline
\end{tabular}

Id. § 4 . 
assured, "may be met by filling vacancies and new jobs approximately on the basis of one minority craftsman for each non-minority craftsman." 107 A footnote amplified on the propriety of this practice: "The one for one ratio in hiring has been judicially recognized as a reasonable, if not mandatory, requirement to remedy past exclusionary practices."108

\section{B. The Conflict Between the Plan and the 1964 Civil Rights Act}

The Philadelphia Plan is vulnerable to many criticisms, both methodological ${ }^{109}$ and legal. Most important, at least for the purpose of this

107 Id. § 3(f).

108 Id. \& 3(f) n.**.

109 The accuracy of the Department of Labor's figures, both as to vacancy rates in the crafts of the availability of qualified minority personnel, have been roundly criticized. Hearings on the Philadelphia Plan and \$ 931, supra note 8, at 62-64. The vacancy rate computations, for example, count people who leave the industry for whatever reason without making any allowance for returnees. Moreover, these estimates are based on continued growth in the crafts in question, an assumption that time has shown to be unwarranted.

Far more troubling are the available minority manpower calculations and the Department's use of the "impact on the existing labor force" test. For these purposes, it is useful to break down the affected work force into three groups: journeymen, apprentices, and other relatively unskilled workers; skilled workers; and new workers. The first group presents the strongest case for a program of the Philadelphia Plan variety. The implementation order states that there are: "7500 minority persons in the Laborers Union who are working side by side with journeymen in the performance of their crafts .... Many of these persons are working as helpers to the journeymen in the designated trades." Implementation Order, supra note 5, § 3(b). Arguably, many of these persons could perform the work of journeymen successfully with little or no additional training. It is also probable that, but for the discriminatory practices of the unions involved, many of them would in fact be journeymen. It is thus plausible to suggest that contractors, when filling positions for journeymen, be obliged to contact and consider qualified members of this labor pool. However, it would be far more equitable to place the onus of this screening process on the discriminating unions rather than on the contractors; and at the very least some assurance that the latter would be free from union reprisals for engaging in a broadened recruitment program of this kind should have been obtained before so burdening them.

The "between 1200 and 1400" skilled minority craftsmen who supposedly were "available for employment" in the construction trades or who "had previous work experience" there, Implementation Order, supra note 5, § 3(b), appear to have consisted almost exclusively of members of the latter group. Such skilled employees were already working, by and large in industry, and were not readily available for employment in the crafts.

The Plan also stated that there were "between 5000 and 8000 prospective minority craftsmen prepared to accept training." Id. Clearly, the bulk of new minority membership in the construction trades would come from this group. The parties with whom they would be competing for positions, however, were not the members of the crafts union, as the Department of Labor suggested, but the pool of unskilled whites. The Department made no finding that hiring blacks and whites on a one-to-one ratio (which is necessary to meet the Plan's "goals") was in any way reflective of the proportions of each racial group in the joint unskilled labor pool. Quite probably it was not, and almost certainly there were more whites than blacks in this group of putative craftsmen. Thus, use of a one-to- 
comment, it seems clear that when the Plan was put into effect, its provisions were contrary to the will of Congress as expressed in the 1964 Givil Rights Act. In Title VI of that Act, Congress made a reasoned and careful response to the problem of employment discrimination in programs and activities that receive federal financing. Section 601 banned such discrimination when based on "race, color, or national origin."110 Although section 602 permitted agency rule making to effect the purposes of the Act, ${ }^{111}$ substantial restrictions were placed on agency discretion. First, the agencies were to develop guidelines only on a project-by-project basis. Second, no regulation so developed was to go into effect without the approval of the President. Finally, no major sanction for violation of a rule promulgated under the authority of the subchapter was to be imposed without prior consultation with "the committees of the House and Senate having legislative jurisdiction over the program or activity involved." 112

These qualifications on agency rule making powers manifest a clear congressional intent to subject agency regulations to close scrutiny by both the legislative and executive branches. On this ground alone, the Philadelphia Plan would seem to have been highly vulnerable to attack. Congress placed, however, a further and even more formidable limitation on agency action. Section 604 of the Act provided: "Nothing contained in this subchapter shall be construed to authorize action under this subchapter by any department or agency with respect to any employment practice of any employer, employment agency, or labor organization except where a primary objective of the Federal assistance is to provide employment." 113 The conclusion seems inescapable that Congress wished to make this sensitive area the exclusive province of the Equal Employment Opportunity Commission (EEOG)

one ratio would result in each black having a better chance to be hired than if he were white, a clear instance of "preferential treatment" in violation of section 703(j) whether or not such a hiring system imposes a "quota."

Inquiry into all of these factual questions was, unfortunately, foreclosed by the Third Circuit, which held that the plaintiffs had waived any challenge they might have had to the accuracy of the Department's figures. Contractors Ass'n v. Secretary of Labor, 442 F.2d 159, 177 (3d Cir. 1971).

11042 U.S.C. $\$ 2000$ d (1970).

111 Section 602 provided:

Each Federal department and agency which is empowered to extend Federal financial assistance to any program or activity, by way of grant, loan or contract other than a contract of insurance or guaranty, is authorized and directed to effectuate .... [section 601] by issuing rules, regulations or orders of general applicability which shall be consistent with the objective of the statute authorizing the financial assistance in connection with which the action is taken.

Id. § 2000d-1 (1970) (emphasis added).

112 Id.

113 Id. § 2000d-3 (1970) (emphasis added). 
in order to avoid the imposition of conflicting obligations on employers, employment agencies, and labor organizations, and that the Philadelphia Plan is in direct conflict with this intent.

Proponents of the Plan attempt to counter this argument by distinguishing between what Congress refused to require in Title VII and what it expressly prohibited. The Plan, they argue, derives its authority not from Title VI but from Executive Order No. 11,246, which does not contain any of the Title VI limitations. And since the Executive Order itself has the force of law, the Plan that was adopted pursuant to it must be valid as well. ${ }^{114}$ Several responses can be made to this position. First, as discussed above, ${ }^{115}$ Congress need not expressly prohibit executive action in order to render it impermissible. It is, or should be, sufficient that Congress has considered the subject concerning which the executive branch is asserting authority and has declined to give the executive the power to act in the way that it thinks appropriate. Second, if an express prohibition were necessary to curtail the executive's power to act, section 604 can be interpreted as exactly that. Although it applies only to actions "authorized under this subchapter," this limitation cannot be construed as congressional approval of a directly contrary approach to the problem by agencies of the executive branch. Rather, that section can be most logically understood as the product of congressional concern that too many cooks might spoil the fair employment broth and as a means of avoiding the imposition of conflicting obligations on those who had engaged in employment discrimination. ${ }^{116}$

Finally, premising the legality of the Plan on the authority of the Executive Order resolves nothing, since it is not entirely clear that the Plan is consistent with the Order's provisions. Although section 201 directs the Secretary of Labor to adopt rules and regulations "necessary and appropriate" to effectuate the purposes of the Order, the Order required government contractors to pledge only that they would not discriminate against any employee or applicant for employment because of race, color, or national origin, and that they would take "affirmative action" to insure that members of minority groups are

114 This position is boilerplate in articles supporting the Plan. See authorities cited note 8 supra, first paragraph.

115 See text and notes at notes 66-70 supra.

116 Perhaps the most famous instance of this problem is Papermakers Local $189 \mathrm{v}$. United States, 416 F.2d 980, 984-85 (5th Cir. 1969), cert. denied, 397 U.S. 919 (1970). There, in 1965, the EEOC allowed the implementation of one seniority plan only to have the OFCC insist that it was inadequate and demand another. Then, in 1968, the Department of Justice successfully brought suit to prevent the implementation of either plan so that it could impose still more stringent requirements. 
not disfavored in "recruitment or recruitment advertising," "layoffs or termination," or "application for training, including apprenticeship."117 It is at least arguable that since the Plan, to be implemented successfully, must require employers to fill job openings on a one-toone, minority-to-nonminority basis, it forces them to violate the nondiscrimination pledges that the Order requires. ${ }^{118}$

It would, however, serve little purpose to press this point in view of the executive branch's acquiescence in, ${ }^{119}$ and, indeed, defense of, 120 the Secretary of Labor's interpretation of the Order. Nonetheless, there remains the question whether the Order, together with the gloss given it by the Philadelphia Plan, has, as its proponents claim, the force of law. The arguments that have been raised concerning this issue have been dealt with above. ${ }^{121}$ Supporters of the Plan rely primarily on the fact that Title VII specifically recognized the existence of ${ }^{122}$ and approved $^{123}$ the executive order program as it then stood, and that subsequent modifications in the program, while admittedly not authorized by the Act, are nevertheless valid because not expressly prohibited by it. ${ }^{124}$ This position is, however, incorrect. Congress can be deemed to have ratified only that which was actually before it; and, while Congress need not expressly disapprove a course of conduct in order to prohibit the executive branch from embarking on it, nevertheless, a prohibition "in so many words"125 can be found here, in the inclusion of section $703(\mathrm{j})$ and the defeat of proposed section $711(\mathrm{~b}) .{ }^{126}$ The Attorney General has admitted that the Philadelphia Plan must fall

117 Exec. Order No. 11,246, 3 C.F.R. 402, 403 (1970), 42 U.S.G. § 2000 e (1970).

118 See note 109 supra.

119 See note 5 supra.

120 See, e.g., 42 Op. ATr'y GEN. No. 37 (Sept. 22, 1969). See also text at notes 141-42 infra.

121 See text at notes 66-77 supra.

122 Section 709(d), 42 U.S.C. $\$ 2000$ e-8(d) (1970), set out at note 79 supra.

123 Section 1103, 42 U.S.C. $\$ 2000 \mathrm{~h}-3$ (1970), set out at note 79 supra.

124 The Department of Labor takes the position that even if Title VII were deemed to limit affirmative action under the Executive Order, the Plan would still be lawful because section 703(j) prohibits "preferential treatment" that is "on account of" racial imbalance, while the Plan is remedial and was imposed because of systematic discrimination in the construction industry. Office of the Solicitor, U.S. Dep't of Labor, Legal Memorandum, Hearings on the Philadelphia Plan and S. 931, supra note 8, at 255, 270. This approach has mustered a good deal of support in cases in which courts found that discrimination had occurred but where the relief sought appeared at first glance to conflict with section $703(\mathrm{~h})$. For a discussion of the effect of this doctrine on the legality of the Philadelphia Plan, see text and notes at notes 163-67, 177-78 \& 184-86.

125 Youngstown Sheet \& Tube Co. v. Sawyer, 343 U.S. 579, 602 (1952) (Frankfurter, J., concurring).

126 See text at notes 72-77 supra. 
if it was in actual conflict ${ }^{127}$ with the provisions and intent of the 1964 Civil Rights Act. Until late in 1969, the conflict was clear.

Discerning legislative intent, however, is always a difficult undertaking. The problems involved in the task are compounded by the fact that this elusive datum is not somehow frozen like a fly in amber, but dynamic and responsive to political and social pressures. Thus, while Congress, when it passed the 1964 legislation, seems clearly to have rejected the Philadelphia Plan's approach to employment discrimination, the executive branch's steadfast insistence on the program could not help but have an impact on Congress. The legislature's first major appraisal of the Plan occurred late in 1969, when an attempt was made to cut off funds to projects operating under such affirmative action requirements. This measure-the so-called Fannin rider-was narrowly defeated, a fact that has led some authorities to argue that Congress thereby ratified the executive's claim of authority to formulate and institute such programs. ${ }^{128}$ Although this position does not seem correct, the tale of the defeat of the Fannin rider warrants some attention.

\section{G. Implied Congressional Ratification of the Philadelphia Plan}

The Comptroller General's objections to the Philadelphia Pre-Award Plan have been outlined above. ${ }^{129} \mathrm{He}$ considered the Plan impermissible because it lacked definite standards for judging the acceptibility of the affirmative action programs that it required. The Secretary of Labor responded to this objection by setting up the goal-range system of the Revised Philadelphia Plan. ${ }^{130}$ Nevertheless, the Comptroller subsequently found the Revised Plan illegal on the ground that it set up quotas in violation of Title VII, and he refused to approve expenditures on projects covered by it. ${ }^{131}$ This view was immediately controverted by the Attorney General, who issued an opinion declaring the Plan to be legal, and advised the Secretary of Labor to disregard the Comptroller General's opinion and to continue to administer the Revised Plan. ${ }^{\mathbf{1 3 2}}$

The Comptroller General responded by urging the Senate Subcom-

12742 Op. ATT'y Gen. No. 37, at 11 (Sept. 22, 1969).

128 See, e.g., Office of the Solicitor, U.S. Dep't of Labor, Legal Memorandum, Hearings on the Philadelphia Plan and S. 931, supra note 8, at 255, 263-64; Jones, supra note 8, at 394-98.

120 See text at notes 85-90 supra.

130 The Comptroller General agreed that this met his vagueness objection. 49 CoMP. GEN. 59, 63 (1969).

131 Id. at 71 .

13242 Op. Atr'y Gen. No. 37 (Sept. 22, 1969). 
mittee on Deficiencies and Supplementals to include in a pending supplemental appropriations bill a "limitation on the use of funds to finance any contract requiring a contractor or subcontractor to meet, or to make every effort to meet, specified goals of minority group employees." ${ }^{133} \mathrm{He}$ also expressed the belief that the refusals of the Attorney General and the Department of Labor to acquiesce in his finding that the Plan was illegal "presented a substantial threat to the legislative control of the expenditure of government funds."134 The Committee accepted this suggestion and attached a rider to the bill that contained continuing resolutions for the Office of Economic Opportunity, the Department of Health, Education and Welfare, the Agency for International Development, and the Department of Labor. ${ }^{135}$ The rider provided: "No part of the funds appropriated or otherwise made available by this or any other act shall be available to finance, either directly or through any Federal aid or grant, any contract or agreement which the Comptroller General of the United States holds to be in contravention of any Federal Statute."136 The prorider forces contended that the provision was merely a reaffirmation of existing law. The question, according to them, was whether an opinion of the Comptroller General's could be overruled by the Attorney General. They claimed that if the rider were defeated, the independence of the Comptroller General from the executive branch would be destroyed. The dignity and authority of Congress were at stake. ${ }^{137}$ Time and again, however, the real issue became apparent. The purpose of the rider was clearly to affirm the congressional intent in the 1964 Civil Rights Act to outlaw programs like the Philadelphia Plan.138 Any ambiguity on this point was removed when the Senate rejected amendments to the rider that would have limited its effect to resolving the dispute concerning the respective powers of the Comptroller General and the Attorney General. ${ }^{139}$ The Senate passed the rider as

133115 CoNG. REc. 40,018, 40,019 (1969).

134 Id.

135 See Washington Post, Dec. 20, 1969, at A-1, col. 6.

136115 CoNG. REC. 40,013 (1969).

137 See, e.g., id. at 39,963 (1969) (remarks of Senator Allott). Sections of the Budgeting and Accounting Act of 1921, which established the Office of the Comptroller General, were also relied on to support this position. These sections were: 31 U.S.C. $\$ 44$ (1970); 31 U.S.C. § 74 (1970); and 31 U.S.C. \& 65 (1970), which directs the Comptroller General to determine whether "financial transactions have been consummated in accordance with laws, regulations, or other legal requirements."

138 See, e.g., 115 Cong. REc. 39,961 (1969) (remarks of Senator Hruska).

139 Senator Javits proposed an amendment that would have allowed judicial review to "any person aggrieved" by a decision of the Comptroller General, as provided by the Administrative Procedure Act. Id. at 39,973 (1969). Presumably, this would have allowed 
drafted,,$^{140}$ and it went to the House for approval.

The White House exerted enormous pressure in order to influence the crucial House vote. ${ }^{141}$ President Nixon issued a statement in which he threatened to veto the supplemental appropriations bill if it contained the unwanted rider. ${ }^{142}$ In the House, as in the Senate, proponents of the rider argued that the issue was simply the preservation of Congress's power over the purse, but their opposition to the substance of the Philadelphia Plan was manifest. ${ }^{143}$ After vigorous debate, the rider was defeated by the House, ${ }^{144}$ and, on reconsideration, the Senate also defeated the measure. ${ }^{145}$ The Administration had its victory; the Philadelphia Plan was saved.

What can be made of these events? On the one hand, the doctrine of ratification by appropriation seems to apply. Under this doctrine, courts view an appropriation by Congress to carry out the provisions of an executive order ${ }^{146}$ or the actions of an administrative agency ${ }^{147}$ as an expression of approval of the executive policy involved, provided that Congress is fully aware of the specific order or interpretation of authority that it thereby supports. ${ }^{148}$ It seems fair to charge Congress

judicial resolution of the question of the Plan's legality. The amendment was defeated, forty to forty-four. Id. at 39,974 (1969).

140 The vote was seventy-four to zero, with twenty-six abstentions. Id. at 40,039 (1969). 141 Just before the House was to convene, Secretary of Labor Shultz and Assistant Secretary of Labor Fletcher held a news conference, in which Mr. Shultz implored members of the House to defeat the rider, calling the vote "the most important civil rights vote in a long, long time," and Mr. Fletcher asserted that the Plan was the "last opportunity to narrow the income distribution gap between whites and blacks. . . . The name of the game ... is to put economic flesh and bones on Dr. [Martin Luther] King's dream." N.Y. Times, Dec. 21, 1969, at 39, col. 1 (city ed.).

142115 Cong. REC. 40,906 (1969) (second such statement on page). The President's remarks began: "[T] he House of Representatives now faces an historic and critical civil rights vote." Id.

143 Congressman Mahon was typical in this respect. Pushing the strategy of those who favored the rider, he began by saying that the issue before Congress was solely "the power of the Congress over the Federal purse." Id. at 40,902-03 (1969). But he continued: "If Congress wanted to change the law and permit the establishment of quotas ... that would be something that the Congress could do. But that is not the law at the present time ...."Id. at 40,904 .

144 The vote in the House was 208 to 156. Id. at 40,921 (1969).

145 The margin in the Senate was thirty-nine to twenty-nine. Id. at 40,749 (1969).

148 Fleming v. Mohawk Co., 331 U.S. 111, 116, 119 (1946); Isbrandtsen-Moller Co. v. United States, 300 U.S. 139, 147 (1937); Swayne \& Hoyt Ltd. v. United States, 300 U.S. 297, 301-02 (1987).

147 Brooks v. Dewar, 313 U.S. 354, 360-61 (1940).

148 Thus, for example, the doctrine did not apply where Congress was unaware that the particular action challenged was illegal and disputed, Federation of Civic Ass'ns, Inc. v. Airis, 391 F.2d 478, 481-82 (D.C. Cir. 1968); or where Congress had merely appropriated a lump sum to the operative authority without devoting a specific line item to the phase of the program under attack. Ex parte Endo, 323 U.S. 283, 303 n.24 (1944). 
with full awareness of the conflict between the Philadelphia Plan and Titles VI and VII. ${ }^{149}$ On the other hand, the Comptroller General could point to a long line of opinions by his office, never before challenged, that had held illegal the unilateral imposition by the executive of contract terms and conditions that, although socially desirable, would lessen competition or increase government expenditures. $^{150}$ Such conditions could only be inserted pursuant to express statutory authorization, ${ }^{151}$ and the Attorney General admitted that Congress had never explicitly authorized the Philadelphia Plan's requirements.

This issue cannot be resolved by mustering narrow ${ }^{152}$ doctrinal arguments. It involves the fundamental constitutional principle of separation of powers. The ratification-by-appropriation doctrine can have a pernicious effect when, as here, the judgment of Congress is influenced by having to pass on a proposal attached to an appropriations package, the enactment of which is a matter of pressing urgency. It is far from clear that a direct vote on the Philadelphia Plan, unencumbered by considerations of what effect the vote would have had on the continuing operation of vital government agencies, would have resulted in the Plan's vindication. Furthermore, given the enormous potential for executive usurpation of congressional prerogatives-the Viet Nam war is, of course, a vivid example of this potential becoming fact-it is prudent to confine the doctrine to the narrowest possible scope. The events surrounding the Fannin rider are a perfect illustration of "the arrogance of the executive branch and the pusillanimous nature of the legislative branch of our national government." 153 The defeat of the rider was engineered by the executive branch and, while this outcome may have expressed the actual wishes of a majority in Congress, a more accurate description of the affair may be the observation made by Senator Javits after the final Senate vote on the rider: "You see now what we can do up here when the President gives some leadership. We can practically accomplish miracles."154

149 See Hearings on the Philadelphia Plan and S. 931, supra note 8, at 139-49.

150 See id. at 145.

151 Cf. Paul v. United States, 371 U.S. 245, 252 (1963).

15242 Or. ATT'Y GEN. No. 37, at 2-4.

153 Kurland, The Impotence of Reticence, 1968 Duke L.J. 619, 620 (1968) (describing Congress's failure to meet the challenge made by the Under Secretary of State to with. draw the Tonkin Bay Resolution).

154 Semple, Philadelphia Plan: How White House Engineered Major Victory, N.Y. Times, Dec. 26, 1969, at 20, col. 1 (city ed.). 


\section{The Philadelphia Plan and the Equal Employment OPPORTUNITY ENFORCEMENT AGT OF 1972}

The defeat of the Fannin rider gave new impetus to the OFCG program, resulting in its expansion to several other metropolitan areas ${ }^{155}$ and its imitation on a lesser scale by state government agencies. ${ }^{156}$ Experience demonstrated, however, two major defects of the Philadelphia Plan approach to employment discrimination in the building trades. The first problem was what came to be called motorcycle compliance. A contractor would concentrate all of his minority employees on his federal jobs, thus achieving his goals without increasing the total number of minority employees in his work force. ${ }^{157}$ The Department of Labor responded to this avoidance technique by requiring the contractor to extend his affirmative action program to all of his job sites, whether or not they were connected with the federal project.158

There was, in addition, general dissatisfaction with having the OFCG or federal contracting agencies impose goals of minority employment rather than allowing the goals to be developed independently by local employers, unions, and minority group organizations. It was thought that imposition of goals by the agencies was likely to heighten the resistance of affected employers and unions and to result in a program less sensitive to local employment conditions and minority group concerns. ${ }^{159}$ Because of this, "home town" solutions came to be favored. Under this approach, the OFCG provided model affirmative action programs, ${ }^{160}$ which interested parties on the local level could then

155 The Seattle, Washington, Chicago, and St. Louis plans are among the more notable. These developments are traced out in Coney, supra note 8, at 17-22; Nash, supra note 8, at 233-34, 236-49. As of October, 1971, forty-four metropolitan areas were operating under some variety of OFCC program, and plans were under study for fifty-six more regions. Hearings on S. 2515, S. 2617, and H.R. 1746 Before the Subcomm. on Labor, Senate Comm. on Labor and Public Welfare, 92d Cong., 1st Sess., at 78 (1971) (statement of L.H. Silberman, Under Secretary of Labor).

150 The state plans have been the subject of much litigation. See Builders Ass'n v. Ogilvie, 327 F. Supp. 1154 (S.D. Ill. 1971); Joyce v. McCrane, 320 F. Supp. 1184 (D.N.J. 1970); Weiner v. Cuyahoga Community College, 238 N.E.2d 839 (1968), aff'd mem., 249 N.E.2d 907 (1969), cert. denied, 396 U.S. 1004 (1969).

157 See Nash, supra note 8, at 240.

15841 G.F.R. $\S 60-1.40$ (1972). See also U.S. Dep't of Labor News Release No. 108 (Feb. 19, 1971).

150 Nash, supra note 8, at 245-46.

160 I CCH Employment Practices Guide If 5015 (1970). See also 41 G.F.R. pt. 60-5 (1972) (Washington Plan); 41 C.F.R. pt. $60-6$ (1972) (San Francisco Plan); 41 C.F.R. pt. 60-7 (1972) (St. Louis Plan); 41 C.F.R. pt. 60-8 (Atlanta Plan). General guidelines for the development of satisfactory affirmative action programs in nonconstruction industries are set out at 41 C.F.R. pt. 60-2 (1972) (Order No. 4). 
tailor to the exigencies of local conditions; the OFCC would intervene and impose its own standards only if the local efforts proved inadequate. ${ }^{161}$ These measures, taken in conjunction, served both to make the program more effective, and to make it more acceptable to those affected by it.

While these revisions of the executive order program were being undertaken, several of the plans that had been instituted under the program, or under similar state programs, were subjected to challenges in the courts. ${ }^{162}$ In each instance, the court sustained the executive's actions, holding that the relevant federal or state executive order constituted independent legal authority for imposing affirmative action requirements, whether or not such relief would have been available in suits brought under Title VII. The best analysis of the question of executive authority appeared in Contractors Association v. Secretary of Labor, ${ }^{163}$ in which the Third Circuit upheld the Philadelphia Plan. The court approached the separation-of-powers issue by attempting to place the executive's action into one of Mr. Justice Jackson's three categories. ${ }^{164}$ It decided that executive authority in the fair employment area had been accepted by Congress as a power distinct from its own, and that, therefore, the Philadelphia Plan fell into what Mr. Justice Jackson called the "zone of twilight," in which "congressional inertia, indifference or quiescence may . . enable, if not invite, measures on independent presidential responsibility."165

While this may be an accurate description of the first twenty years of

161 Nash, supra note 8, at 245. This extensive reliance on the efforts of local interests to develop workable affirmative action programs has been criticized as dilatory and ineffective. Coney, supra note 8, at 17-18. Nonetheless, of the forty-four plans operating as of October, 1971, thirty-eight had been arrived at through voluntary negotiations, while only six had been imposed. Hearings on S. 2515, S. 2617, and H.R. 1746, supra note 155, at 78.

162 Contractors Ass'n v. Secretary of Labor, 442 F.2d 159 (3d Cir. 1971); Builders Ass'n v. Ogilvie, 327 F. Supp. 1154 (S.D. Ill. 1971); Joyce v. McCrane, 320 F. Supp. 1184 (D.N.J. 1970); Ethridge v. Rhodes, 268 F. Supp. 83 (S.D. Ohio 1967); Weiner v. Guyahoga Community College, 238 N.E.2d 839 (1968), aff'd mem., 249 N.E.2d 907, cert. denied, 396 U.S. 1004 (1969).

163442 F.2d 159 (3d Cir. 1971).

164 See Youngstown Sheet \& Tube Co. v. Sawyer, 343 U.S. 579, 635-38 (1952) (Jackson, J., concurring).

165 Id. at 637. In this respect compare Mr. Justice Frankfurter's analysis, also in Youngstown, of the limitations on executive authority under our constitutional system:

It is an inadmissibly narrow construction of American constitutional law to confine it to the words of the Constitution and to disregard the gloss which life has written upon them. In short, a systematic, unbroken executive practice, long pursued to the knowledge of Congress and never before questioned, engaged in by Presidents who have also sworn to uphold the Constitution, making as it were such exercise of power part of the structure of our government, may be treated as a gloss on "executive power" vested in the President by \& 1 of Article II.

Id. at 610-11 (concurring opinion). 
the executive order program, it is impossible to characterize the Civil Rights Act of 1964 as "congressional inertia, indifference or quiescence," whatever else might be said of it. In that Act, Congress clearly addressed the concerns that triggered the Philadelphia Plan, and provided a method for their vindication different from that instituted by the executive. Thus, the Plan more accurately falls into Mr. Justice Jackson's third category: a measure "incompatible with the express or implied will of Congress," which can be sustained "only by disabling Congress from acting upon the subject."168 The court seems simply to have misinterpreted a rather unambiguous, if unpleasant, legislative history. ${ }^{107}$

Whether or not these judicial decisions were correct, they carried great weight when, in mid-1971, Congress undertook an evaluation of the impact of Title VII and the related executive order program on the problems of employment discrimination. This review resulted in congressional ratification of the executive's affirmative action requirements.

The story emerges from the tangle of legislative debates only with some difficulty. Consideration of Title VII began in 1971 when House committee hearings were held concerning primarily two problems: (1) what additional enforcement powers should be granted to the EEOC; and (2) whether there should be consolidation of the OFCC's contract compliance procedures, the EEOC's antidiscrimination programs, and the Attorney General's pattern-or-practice litigation into a single, coordinated effort. The two problems were obviously interrelated, since any new powers granted to the EEOG would depend on the amount of consolidation deemed advisable. Debate in the House centered primarily on whether addition of the OFCG's program to the other duties of the EEOG would be administratively feasible. Fears were expressed that the EEOC's massive backlog of work would be unduly increased by the OFCG procedures, especially since the new agency would have no experience with them. ${ }^{168}$ On the other hand, it was argued that centralization of fair employment programs would avoid overlapping and conflicting agency action and pro-

168 Id. at 637-38 (Jackson, J., concurring).

187 See text and notes at notes 61-65 \& 71-79 supra.

168 See, e.g., Hearings on H.R. 1746 Before the Gen. Subcomm. on Labor of the House Comm. on Educ. and Labor, 92d Cong., Ist Sess., at 79, 81-82, 84-85 (statement of W.H. Brown, EEOC Chairman). A number of witnesses also expressed the fear that the merger of the OFCC into the EEOC would weaken the former's contract compliance program. See generally id. at 53-78 (statement and testimony of L.F. Silberman, Under Secretary of Labor, and testimony of A. Fletcher, Assistant Secretary of Labor). 
mote a more efficient enforcement effort. ${ }^{169}$ There were proponents of strong civil rights legislation on both sides of the question, and very little attention was directed to the propriety of the substantive remedies available under the OFCC program.

This issue was clearly raised, however, when Congressman Dent offered an amendment by way of a substitute to H.R. 1746, the main bill in the House. In addition to extensive treatment of the matters discussed above, the amendment proposed by Congressman Dent contained a section 717(f), which provided that: "All authority, functions, and responsibilities of the OFCG ... are transferred to the Equal Employment Opportunity Commission. ... The Commission shall be prohibited from imposing or requiring a quota or preferential treatment with respect to number of employees or percentages of employees of any race, color, religion, sex, or national origin."170 The import of this section was somewhat ambiguous, since proponents of the Philadelphia Plan had taken great pains to insist that no quotas were imposed under it. Congressman Pucinski questioned Congressman Dent closely on this point, however, and in the resulting discussion Dent made it clear that he intended the provision to prohibit all government agencies from imposing any form of standards concerning the numbers of minority workers employed.171

The Dent amendment was defeated.172 Thus the House did not confront the issue of Philadelphia Plan requirements in isolation, but rather as part of a larger package that, taken as a whole, it viewed as less acceptable than the principal alternative measure before it. Nevertheless, the House vote, with that significant ambiguity, can be taken as a rejection of the notion that goals and ranges of minority employment have no place in antidiscrimination programs.

The treatment of this issue in the Senate was more elaborate and the result more clear cut. In a series of four major battles, Senator Ervin's carefully orchestrated attack on the executive order program was defeated, and its affirmative action concept approved by the Senate. Like the House debate, discussion of the Philadelphia Plan in the Senate became entangled with separate issues involving the proper jurisdiction and enforcement powers to be conferred on the restructured

169 See, e.g., id. at 106-09, 115-16, 120-21, 128 (statement and testimony of H.A. Glickstein, Staff Director, U.S. Comm'n on Civil Rights).

170 The Dent Amendment is printed in its entirety at 117 CoNG. REc. H 8481-85 (daily ed. Sept. 15, 1971). Section $717(\mathfrak{f})$ appears $i d$. at $\mathrm{H} 8484$.

171 Id. at $\mathrm{H} 8475$.

172 Id. at $\mathrm{H} 8540$ (daily ed. Sept. 16, 1971). This measure was then passed by the House $I d$. at $\mathrm{H}$ 8541-42. 
EEOG. But the Senate debate eventually isolated the substance of the executive program and expressly ratified it.

Senator Ervin's opening salvo was directed to alleged vacillation and inconsistency in the application of the OFCC's affirmative action guidelines. The Senator claimed that the contracting agencies frequently accepted a contractor's affirmative action program, and the contractor would then proceed in reliance on this approval only to have the OFCC review the program at a later date and find it inadequate. ${ }^{173}$ Since this complaint did not go to the substance of the programs, pro-Philadelphia Plan forces-when assured that the language would not force the OFCC to accept programs that offered only token compliance ${ }^{174}$-agreed to an amendment affording federal contractors protection against this practice. ${ }^{175}$

The second step in the sequence was Senator Ervin's support of efforts to merge the OFCG program into the EEOC. Senator Javits, an advocate of the Philadelphia Plan approach, ${ }^{178}$ argued that, while the proposed merger was not intended by the Senate committee reporting the legislation "to alter in any way the scope or meaning of the executive order program," nevertheless, "administering different standards under title VII and the Executive order" might create "confusion" in the EEOC and result in a "watering down of the Executive order program." 177 In fact, it is likely that this would have been the result. The EEOC would not have been able to avail itself of the OFCC's argument that its authority was "independent" of Title VII's strictures, and would have been obliged to square the goals provisions of the affirmative action plans with the language of section $703(\mathrm{j}) .{ }^{178}$ In any

173 See generally 118 CoNg. REc. S 578-80 (daily ed. Jan. 26, 1972) (remarks of Senator Ervin).

174 See generally id. at S 579-80 (remarks of Senator Javits). See also id. at S 632 (daily ed. Jan. 27, 1972).

$175 \mathrm{Id}$. at $\mathrm{S}$ 632-33. The amendment as eventually adopted provided:

No Government contract, or portion thereof, with any employer, shall be denied, withheld, terminated, or suspended, by any agency or officer of the United States under any equal employment opportunity law or order, where such employer has an affirmative action plan which has previously been accepted by the Government for the same facility within the past twelve months without first according such employer full hearing and adjudication under the provisions of 5 U.S.C. $\$ 554$, and the following pertinent sections. Provided, however, That if such employer has deviated substantially from such previously agreed to affirmative action plan, this section shall not apply. Provided further, That for the purposes of this section an affirmative action plan shall be deemed to have been accepted by the Government at the time the appropriate compliance agency has accepted such plan unless within 45 days thereafter the Office of Federal Contract Compliance has disapproved such plan.

176 Senator Javits was the most vigorous opponent of the Fannin rider in the Senate. See text at notes 129-145 supra.

177118 CoNG. REc. $S 163$ (daily ed. Jan. 20, 1972).

178 Some commentators believed this to be possible. See note 82 supra. This position 
case, the Senate, like the House, defeated the merger provision, again with pro-civil rights forces divided as to the efficacy of a unified enforcement effort. ${ }^{179}$

The rejection of the consolidation proposal left the OFCG program alive and operating under the judicially sanctioned, "independent" authority of Executive Order No. 11,246. Senator Ervin therefore proposed another amendment, this one providing that: "No department, agency, or officer of the United States shall require an employer to practice discrimination in reverse by employing persons of a particular race, or a particular religion, or a particular national origin, or a particular sex in either fixed or variable numbers, proportions, percentages, quotas, goals, or ranges."180 This amendment's attack on the Philadelphia Plan concept was patent. Opponents of the measure pointed out that it could also be "read to deprive even the courts of any power to remedy clearly proven cases of discrimination."181 These two reasons for opposing the amendment led to its defeat by a substantial margin..$^{182}$

The Senate thus assessed the OFCC requirements in a setting unconfused by the separate issue of whether to merge that organization into the EEOC, and it refused to reject them. The reasons for this refusal, however, were obscured by the rather strained interpretation that had been placed on the third Ervin amendment. Apparently Senator Ervin thought this to be the case; he introduced a fourth and final amendment in an effort to have the Senate pass upon the legality of Philadelphia Plan requirements without being influenced by any extraneous considerations. This final attempt would have amended section $703(j)$ to proscribe all of the OFCC's affirmative action programs. This was to be done by extending section $703(\mathrm{j})$ to cover explicitly remedies devised under the executive order program. ${ }^{183}$ Sena-

was untenable prior to the recent reenactment of Title VII. See text at notes 179-186 infra. For the text of section 703(j), see text at note 65 supra.

179 The vote is recorded at 118 Cong. REc. S 575-76 (daily ed. Jan. 26, 1972). Apparently the debate concerning the utility of the transfer was in good faith. Compare S. REP. No. 415, 92d Cong., 1st Sess. 29-31 (majority views, favoring consolidation as strengthening overall enforcement effort) with Hearings on S. 2515, S. 2617, and H.R. 1746, supra note 155, at 56-58 (statement of W.H. Brown, EEOC Chairman) and id. at 76, 80-84 (statement of L.F. Silberman, Under Secretary of Labor) (both opposing consolidation because of its supposed adverse impact on civil rights enforcement).

180118 Cong. Rec. S 691 (daily ed. Jan. 28, 1972).

$181 \mathrm{Id}$. at S 705 (remarks of Senator Williams). See also id. at S 693-94 (remarks of Senator Javits).

$182 I d$. at S 705-06. The vote was twenty-two to forty-four. Id. at S 706 .

183 The amendment provided :

Nothing contained in this title or in Executive Order No. 11246, or in any other law or Executive Order, shall be interpreted to require any employer, employment 
tor Ervin thus sought to eliminate any foundation for the Third Circuit's view that since the OFCG's authority was based on the executive order program, it was not subject to the statutory limitations governing suits brought under Title VII. ${ }^{184}$ At the same time, the amendment would have left intact the power of the judiciary to fashion affirmative relief to remedy the present effects of past discrimination. With the issue thus squarely presented, the Senate, by a decisive margin, rejected this final effort to alter the thrust of the OFCC's program, ${ }^{185}$ and at long last unequivocally approved the affirmative action program of the executive. ${ }^{186}$ As a result, the Philadelphia Plan and its progeny are no longer susceptible to challenges premised on the doctrine of separation of powers. ${ }^{187}$

agency, labor organization, or joint labor-management committee subject to this title or to any other law or Executive Order to grant preferential treatment to any individual or to any group because of the race, color, religion, sex, or national origin of such individual or group on account of an imbalance which may exist with respect to the total number or percentage of persons of any race, color, religion, sex, or national origin employed . . . in comparison with the total or percentage of persons of such race, color, religion, sex, or national origin in any community, State, section, or other area, or in the available work force in any community, State, section, or other area.

Id. at S 2275 (daily ed. Feb. 22, 1972).

184 Contractors Ass'n v. Secretary of Labor 442 F.2d 159, 171-74 (3d Cir. 1971), discussed in text at notes 50-52 \& 163-167 supra.

185 The amendment was defeated, thirty to sixty. 118 Cong. REc. S 2276 (daily ed. Feb. 22, 1972).

186 The Senate passed its version of the new Title VII on February 22, 1972. Id. at $S$ 2306. Because there were significant differences between the Senate and the House versions, the bill was sent to conference. The final measure, which was substantially identical to the Senate version, was agreed to by the Senate, id. at S 3460-64 (daily ed. March 6, 1972) and, two days later, by the House, id. at $H$ 1861-71 (daily ed. March 8, 1972). For the text of the conference report, see id. at H 1694-97 (daily ed. March 2, 1972).

187 An argument has been made that the affirmative action requirements of the OFCC contract compliance program violate the fifth amendment rights of nonminority workers by granting preferential treatment to minority employees. While this claim presents difficult questions of law, going somewhat beyond the intended scope of this comment, a tentative answer can be suggested. The OFCC, or a court, could impose a goal, the fulfillment of which would require an employer to make every good faith effort to hire minority employees up to some fixed percentage of the employer's work force, without violating the fifth amendment rights of nonminority employees. But this statement must be carefully qualified. First, since any increase in minority group employment is bound to be disadvantageous to nonminority employees, it seems clear that nonminority workers cannot make out a fifth amendment claim merely by showing that they are in a worse position under an affirmative action program than they were before. Rather they would need to show some kind of injury beyond that resulting from an aliquot division of employment opportunities between minority and nonminority employees. On the other hand, the goal required must bear a reasonable relationship to the expected composition of the work force were the employer to make neutral hiring decisions. Hence, in the absence of significant countervailing evidence, the OFCC or a court might presume that minority and nonminority groups have the same proportion of workers of roughly comparable skills, and therefore set the employer's goals at the proportion of members 


\section{Conclusion}

The interplay between the executive and legislative branches of the federal government in the field of fair employment demonstrates the organic, interdependent nature of the tripartite structure established by the Constitution. Faced with a flat refusal by Congress to legislate against discrimination in employment, four Presidents, over a period of more than twenty years, issued a series of executive orders designed to help alleviate the problem. These largely unsuccessful efforts were superceded in major part by Titles VI and VII of the Civil Rights Act of 1964, which gave the executive branch new sweeping powers with which to combat employment discrimination.

of the discriminated class in the available labor pool. This presumption could of course be modified if experience revealed that it was false.

It also seems clear that majority workers would not make out a fifth amendment claim by showing that minority workers are actively recruited for job positions while nonminority workers are not. Where past discriminatory practices have been demonstrated, special encouragement to minority groups is necessary to insure that they will in fact be able to take advantage of the job opportunities available to them to the same extent as nonminority workers. While increased minority employment is a conscious aim of such a program, that aim is to be achieved only by equalizing the opportunity for putative minority and nonminority workers to be hired. An unequal recruitment effort may be necessary initially to achieve this result, but that does not invalidate the achievement of the otherwise permissible objective of equal employment opportunity. $C f$. Fiss, supra note 8, at 268-76, 281-90.

It is, however, important for the OFCC or a court to view these goals of minority utilization merely as tentative-and extremely rough-approximations of the fair employment ideal. For example, it is possible that the minority labor pool contains a considerable number of older, semiskilled employees who possess qualifications superior to those of the average job applicant. In such circumstances, were minority workers to obtain only an aliquot share of job openings, there would still be evidence that the employer was discriminating against them. On the other hand, a radically different reason for such a cautious approach is seen by considering the extreme case where minority workers are allocated all of a certain class of job opportunities in order to remedy the effect of their past exclusion. In this situation, majority group competitors for those positions are completely deprived of an employment opportunity for which, but for their race, they would have had some chance to bid. The principle remains the same when their opportunity is reduced by any amount below that which would have prevailed had they been members of the minority group. In such circumstances, it would appear that majority workers would be able to sustain a fifth amendment claim.

Thus, in order to avoid a violation of the fifth amendment rights of nonminority employees, an affirmative action program must not require more of an employer than that he make every good faith effort to insure a pro rata allocation of jobs to qualified minority workers. Any percentages of minority utilization adopted to further this objective must be set to reflect the number of such workers one would expect in the employer's labor force if he were making nondiscriminatory hiring decisions. Such standards must necessarily be flexible and inductively computed, based to the greatest possible extent on actual experience. Rigid adherence to them could not, therefore, be required. Rather, they would serve primarily an evidentiary function, requiring the discriminating party to explain significant variations between the actual effects of his hiring practices and the theoretical ideal. For a discussion of this problem, see Carter v. Gallagher, 452 F.2d 315, 327-32 (8th Gir. 1971) (en banc opinion). 
The executive branch believed, however, that these remedies were inadequate. It therefore developed, as a supplementary measure, an affirmative action program of a kind that Congress had rejected as an appropriate means of dealing with the problem. Although this unilateral action by the executive was impermissible under constitutional principles of separation of powers, it was reluctantly acquiesced in by Congress and upheld by the judiciary. Were that the end of the tale, these events would represent nothing more than yet another instance of the executive exercising power in derogation of the prerogatives of Congress. But the matter did not end there. In response to legitimate substantive criticisms of its program, the executive branch modified its approach, correcting the inequities of the Philadelphia Plan and developing a systematic attack on discrimination, fair to employers, unions, and minority groups. ${ }^{188}$ Thus, when Congress subsequently reexamined its position on affirmative action requirements, it was able to, and did, accept the concept developed by the executive as an appropriate standard to govern the OFCG's antidiscrimination activities.

This development is likely to have an impact on the kinds of remedies available under Title VII. The acceptance by Congress, in principle, of specific goals of minority employment as a means of insuring that the effects of past discriminatory practices are not perpetuated is bound to soften the no-quota language of section $703(\mathrm{j}) .{ }^{189}$ The new

188 See text at notes 157-161 supra.

$189 \mathrm{It}$ is true that in disapproving Senator Ervin's efforts to bring the executive order program under 'Title VII, Congress nevertheless left the language of section 703(j) essentially unchanged. Thus, it can be argued that Congress's hostility toward specific standards of minority employment remains intact and should inform decisions by courts in actions brought to vindicate Title VII rights. There are two reasons, however, that this reading should be rejected. The frrst is the potentially sweeping expansion made by Congress in the types of judicial relief available under Title VII. The language of section $706(\mathrm{~g}), 42$ U.S.C. $\$ 2000 \mathrm{e}-5(\mathrm{~g})(1970)$ was amended by inserting the phrases italicized below:

If the court finds that the respondent has intentionally engaged in or is intentionally engaging in an unlawful employment practice charged in the complaint, the court may enjoin the respondent from engaging in such unlawful employment practice and order such affirmative action as may be appropriate, which may include, but is not limited to, reinstatement or hiring of employees, with or without back pay (payable by the ... [entity] responsible for the unlawful employment practice), or any other equitable relief as the court deems appropriate.

P.L. No. 92-261. This language invites innovative executive and judicial enforcement of Title VII, leaving the precise contours of the relief available to be developed on a caseby-case basis. While an absolute insistence on any percentage of minority workers would still run afoul of section 703(j), the requirement of "every good faith effort" to meet reasonable judicially-imposed standards now seems permissible. See note 184 supra.

The second reason for viewing the imposition of such goals as appropriate under Title VII stems from the fact that under the executive order program, they are placed on parties not found guilty of discrimination. Since Congress has approved of so burdening arguably innocent parties, it would be anomalous to consider the same conditions too 
reading of this provision should allow the courts to frame injunctive relief requiring employers and unions that have engaged in discrimination to make good faith efforts to reach satisfactory levels of minority employment. ${ }^{190}$

\section{Robert P. Schuwerk}

onerous to impose on those who have "intentionally engaged in . . . an unlawful employment practice."

190 Until quite recently, courts have generally been very reluctant to find authorization in Title VII for the type of remedial relief undertaken pursuant to the Philadelphia Plan. The decisions fall into three classes. At one extreme is United States v. Ironworkers Local 86, 315 F. Supp. 1202 (W.D. Wash. 1970), affd, 443 F.2d 544 (9th Cir. 1971), in which the court found that the discriminating union's regular apprenticeship programs could "overcome the present effects of past discrimination" by insuring that, "to the extent there are blacks on the list of qualified apprentice applicants," its intake of black applicants never fell below 30 percent. $I d$. at 1247. The court further ordered the locals to set up a special apprenticeship program specifically to cater to older blacks who might wish to enter the trades. Local contractors were obliged to cooperate in these programs and to bear the cost of administering and publicizing them jointly with the unions. Id. at 1247-50. The quota aspect of the Ironworkers decision appears to have been unprecedented; and, indeed, a small number of courts, typified by Dobbins v. Local 212, IBEW, 292 F. Supp. 413, 445 (S.D. Ohio 1968), has specifically rejected all the relief granted in Ironworkers as contrary to section 703(j). In the great majority of cases, courts have opted for a middle position. For example, the imposition of an obligation to publicize a new policy of nondiscrimination and to require the active solicitation of minority workers was deemed appropriate in United States v. Sheetmetal Workers Local 36, 416 F.2d 123, 132-40 (8th Gir. 1969). But in so doing the court felt compelled to remark that "[i]n requiring the modifications, we impose no quotas, we grant no preferences." $I d$. at 133. This approach seems consistent with the content of the executive's affirmative action program at the time Congress enacted Title VII in 1964. But a bolder stance should now be permissible. Since Congress has unequivocally endorsed the OFCC's affirmative action requirements, the Ironworkers case should become the preferred position. Cf. Allen v. City of Mobile, No. 72-1009 (5th Cir., Sept. 7, 1972) (Goldberg, J., dissenting); Castro v. Beecher, 4 F.E.P. 700, 709-10 (1st Gir., Apr. 26, 1972), aff'g in part and rev'g in part, 334 F. Supp. (D. Mass. 1971); Carter v. Gallagher, 452 F.2d 315, 327-32 (8th Cir. 1971) (en banc opinion). 